Revue d'études américaines. American Studies Journal

$2 \mid 2017$

(Hi)stories of American Women: Writings and Rewritings / Call and Answer: Dialoguing the American West in France

\title{
Performing Paint, Claiming Space: The Santa Fe Indian School Posters on Paul Coze's Stage in Paris, 1935
}

Jessica L. Horton

\section{OpenEdition}

Journals

Electronic version

URL: https://journals.openedition.org/transatlantica/11220

DOI: 10.4000/transatlantica. 11220

ISSN: 1765-2766

\section{Publisher}

Association française d'Etudes Américaines (AFEA)

\section{Electronic reference}

Jessica L. Horton, "Performing Paint, Claiming Space: The Santa Fe Indian School Posters on Paul Coze's Stage in Paris, 1935", Transatlantica [Online], 2 | 2017, Online since 13 May 2019, connection on 01 February 2023. URL: http://journals.openedition.org/transatlantica/11220 ; DOI: https://doi.org/ 10.4000/transatlantica. 11220

This text was automatically generated on 1 February 2023.

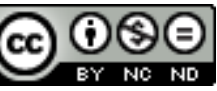

Creative Commons - Attribution-NonCommercial-NoDerivatives 4.0 International - CC BY-NC-ND 4.0 https://creativecommons.org/licenses/by-nc-nd/4.0/ 
Performing Paint, Claiming Space: The Santa Fe Indian School Posters on Paul Coze's Stage in Paris, 1935

Jessica L. Horton

Introduction 
Figure 1

MUSEUM NATIONAL D'HISTOIRE NATURELLE

ART PEAU-ROUGE D'AUJOURD'HUI

Dessins des Eleves de I'Ecole Indienne de Santa Fe, Nouveau Mexique, Etats-Unis presentes par le peintre

\section{PAUL COZE}

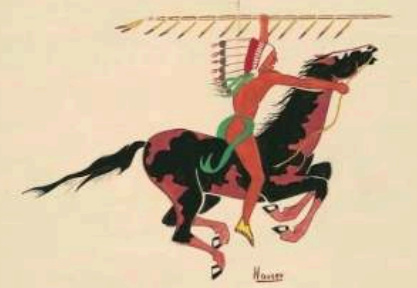

Du 17 Mai au 23 Juin, 1935, au

TROCADERO

Musee d'Ethnographie

(A1) Allan Houser (Chiricahua Apache, 1914-1994), poster announcing Art peau-rouge d'aujourd'hui, 1935. Tempera on paper, 20 in. x 13 in. Location unknown. Courtesy of the Musée du quai Branly, DA000199/32288: Archives du Musée de l'Homme, Série C : Manifestations organisées par le MH 1930-1980. Allan Houser artworks @ C Chiinde LLC, Allan Houser Foundation archives.

Inside the worn edges of a single sheet of paper, a man on horseback wearing a headdress traverses an expanse between authoritative black lines of French text. <figure 1> The spiraled legs and streaming tail of the animal indicate that the pair moves at full gallop. Hand-painted curves and colors contrast with the industrial precision of the printed words. Yet the feathered lance gripped by the rider serves as a compositional bridge, cutting a sharp horizontal line as if to underscore the ponderous lettering of a name that hovers just above, Paul Coze. The artist's own underlined signature, Houser, is diminutive by comparison, tucked beneath the horse's hooves. Tiny pinholes in the corner of the paper attest to the period in which it hung, probably behind glass in a store window or on a marquee on the streets of Paris. The poster announced to pedestrians an exhibition of paintings by contemporary Native American artists, Art peau-rouge d'aujourd'hui (Redskin Art Today) at the Musée d'Ethnographie du Trocadéro (MET), on view from May 17 to June $23,1935 .{ }^{1}$ The subtext offers more clues to this unprecedented event: "Dessins des Eleves de l'Ecole Indienne de Santa Fe, Nouveau Mexique, Etats-Unis, presentes par le peintre, Paul Coze" [sic] (Drawings by students of the Santa Fe Indian School, New Mexico, United States, presented by the painter Paul Coze).

2 The Chiricahua Apache artist Allan Houser (1914-1994), who achieved fame in subsequent decades for his monumental bronze sculptures of Native American subjects, painted the equestrian in April 1935. He enrolled at the Studio School of the Santa Fe Indian School, a federally funded program dedicated to training Native American artists, the previous year. Paul Coze (1903-1974), a Beirut-born Frenchman enamored 
of all things "Indienne," sent a telegraph to the school requesting that some 200 posters be rushed to Paris to announce an exhibition of the students' paintings that was scheduled to open there just three weeks later. To save time, the posters were printed at a local press in Santa Fe, which likely explains why accents are missing from the French words. Houser and his classmates worked through the Easter holiday weekend, adding singular images of tipis, horses, gourd rattles and dancers in tempera paint (Dunn 281). Today, the paintings exhibited at the MET are known only by their reproduction in French magazines of the period. However, sixty-one of the posters have survived. Fifty, most of which are in excellent condition, were acquired by the Museum of Contemporary Native Arts in Santa Fe through a grant from the Toyota Foundation in 1992 (see A2-A51). Six posters remain at the Muséum national d'histoire naturelle in Paris (A52-57); the location of Houser's rider, which was originally among them, is currently unknown. Four posters, at some point folded or cut to obscure the text from display, along with a portion of Paul Coze's archive, were purchased at auction from a private collection by the Musée du quai Branly in 2015 (see A58-A61). ${ }^{2}$ Sitting unseen in storage for much of their history, the posters were severed from the transatlantic milieu that their makers bridged with paint. ${ }^{3}$

3 This essay reunites the traveling works on paper narratively as well as visually, in a digital gallery hosted by an Auburn University wordpress page. It further reconnects them to a variety of agents who collaborated in their production, circulation, and reception. In lieu of a unitary account of authorship, I treat the posters as multivocal elements of a broader assemblage of people and objects that connected the Indigenous Americas to France between the wars. Originating in the work of French philosophers Gilles Deleuze and Félix Guattari, assemblage is "a mode of ordering heterogeneous entities so that they work together for a certain time," without sharing a common identity or intention (Müller 28; Deleuze and Guattari). My use is methodological as well as descriptive, indicating the reassembly of a scattered transnational archive to illuminate how disparate yet conjoined subjects and objects affected the conditions of possibility for Indigenous artists in the 1930s.

4 As the bold, black letters of his name suggest, Coze sought to territorialize the commission, drawing the Studio School into his circle of French boy scouts and hobbyists alongside Native American performers in Paris. His activities built upon the well-known efforts of Dorothy Dunn, the fine arts instructor at the Studio School from 1932-1937, to define the new painting movement as wholly autochthonous, yet he shifted the work into a decidedly theatrical register. Approaching the commission as a fraught collaboration between Coze and the students allows me to both appraise and delimit the roles of colonial agents in dialogue with Native artists who are underrepresented in historical documents. Treating the posters themselves as privileged components of a transatlantic assemblage serves to further illuminate how they affected their material and social environments upon crossing the ocean. I show that the Studio School students answered Coze's invitation to participate in the performance culture of Paris on their own terms, by engendering a dynamic interplay of text and images. The colorful figures played a kind of visual game with French audiences, as auratic paint pushed against, merged with, and occasionally leapt past machine-printed words to engage with the three-dimensional spaces of streets, museums, and stages. 
5 Paint's teasing of text was at first glance consonant with a wider culture of play in Paris, headquarters of jazz and Surrealism between the wars. During this period, objects from Africa, Asia, the Pacific Islands, and, less frequently, the Americas circulated in ethnographic institutions, commercial galleries, avant-garde exhibitions, and flea markets. Likewise, Indigenous musicians and dancers traveled great distances to perform in colonial expositions, circuses, and cabarets. Scholars have shown that French audiences looked to ritual objects and racially-marked bodies deemed exotic in order to escape from, or construct alternatives to, the political volatility of their nation under the shadow of fascism. With a few exceptions, accounts of the cultural politics of interwar Paris are relatively silent regarding the Native artists in Coze's circle, a lacuna that is only partially explained by France's diminished colonial power in the Americas. ${ }^{4}$ I find that the ludic and insistently contemporary address of the posters, like that of the Indigenous performers, does not conform to orthodox accounts of primitivism in interwar Paris. Scholars have focused critical attention on the construction of authenticity, mysticism, and alluring distance. They have reserved serious play for the Surrealists, who assembled the images and material culture of colonized peoples into new configurations to address pressing sociopolitical concerns. I demonstrate that the posters similarly rearranged heterogeneous elements and related cultural categories, undermining those that fetishized Native subjects' premodernity. Because they met Parisians on familiar ground, they became camouflaged in hindsight.

6 The posters are not alone in evading the historiographical spotlight. They are joined by the understudied figures of Coze, Penobscot dancer Molly Spotted Elk, Yakima circus performer Charlie Oskomon, and others who populated the cityscape, wearing feathers in their hair. Nearly all French encounters with Native American material in this period -objects, paintings, books, music, dance, and even films-had Coze's name attached. His childhood fascination with Native Americans blossomed into full-fledged career by the late 1920s. When he wasn't busy collecting in Canada and the United States, writing adventure books, and painting sentimental American Indian portraits, he donned a headdress and banged drums with his pack of French boy scouts at the Cirque du Molière, or led Parisian hobbyists in prayer inside the tipi of his Cercle d'études Wakanda (Wakanda Study Circle). ${ }^{5}$ Coze's multidisciplinary activities engendered interactions among Native material culture, graphic arts, and performing bodies-forms often subjected to institutional and ideological divisions. ${ }^{6}$ At the same time, his circle was entangled with French nationalism, wealthy patronage, and popular entertainment, placing Indigenous artists in tension with more explicit anticolonial projects undertaken elsewhere in the city, notably by the Surrealists.

7 While the commission operated within colonial-capitalist frameworks, I maintain that a subtler politics did unfold on Coze's stage. The French text-and by extension, context -opened new possibilities for exuberant movement that the students were already exploring in graphic form. Hailing primarily from the Southwest and Great Plains, Studio School attendees were born into communities variously displaced by nineteenth-century Indian removal policies, confined by white settlement, and controlled by federal assimilation policies. Amid colonial rupture, strict definitions of authenticity framed the emergence of a modern Native American painting movement. Elite white supporters in the United States sought a uniquely American tradition with deep roots in the past, a perspective supported by Dunn and federal agents of the "Indian New Deal" of the 1930s. Given this fraught legacy, a number of Native Studies 
scholars have privileged performance, particularly Wild West shows and other forms of ethnographic entertainment that flourished on both sides of the Atlantic in the nineteenth and early twentieth centuries, as "the most favourable site" (Phillips 27) for Native Americans to exercise agency and mobility in dire political times (Denzin; Flint; Graham and Penny). Art historian Ruth B. Phillips, for one, writes,

In the early twentieth century, when visual fine arts were confined to static plastic and graphic forms, the added dimensions of performance - temporal, spatial, and vocaloffered better tools for Native intervention. The directness and immediacy of live performance confronted audiences with the fact of the Native performers' contemporaneity and bodily co-presence. (27)

While respecting formal and material differences between graphic and performing arts, I resist the conclusion that Native Americans controlled their cultural expression more directly through physical presence than through the images that circulated in their stead. The posters in particular unfixed the boundary between painted and embodied forms, revealing the categories to be porous and mutable-a condition presaged by Indigenous cultural frameworks that grasp the potential liveness of images as well as bodies.7 For Native makers who stayed behind in an era of increasing confinement, pushing at the borders of text and page was a means of claiming space as surely as those who boarded trains and boats to animate faraway stages.

\section{The "Indian Rome": Coze's Studio School Visit}

Figure 2

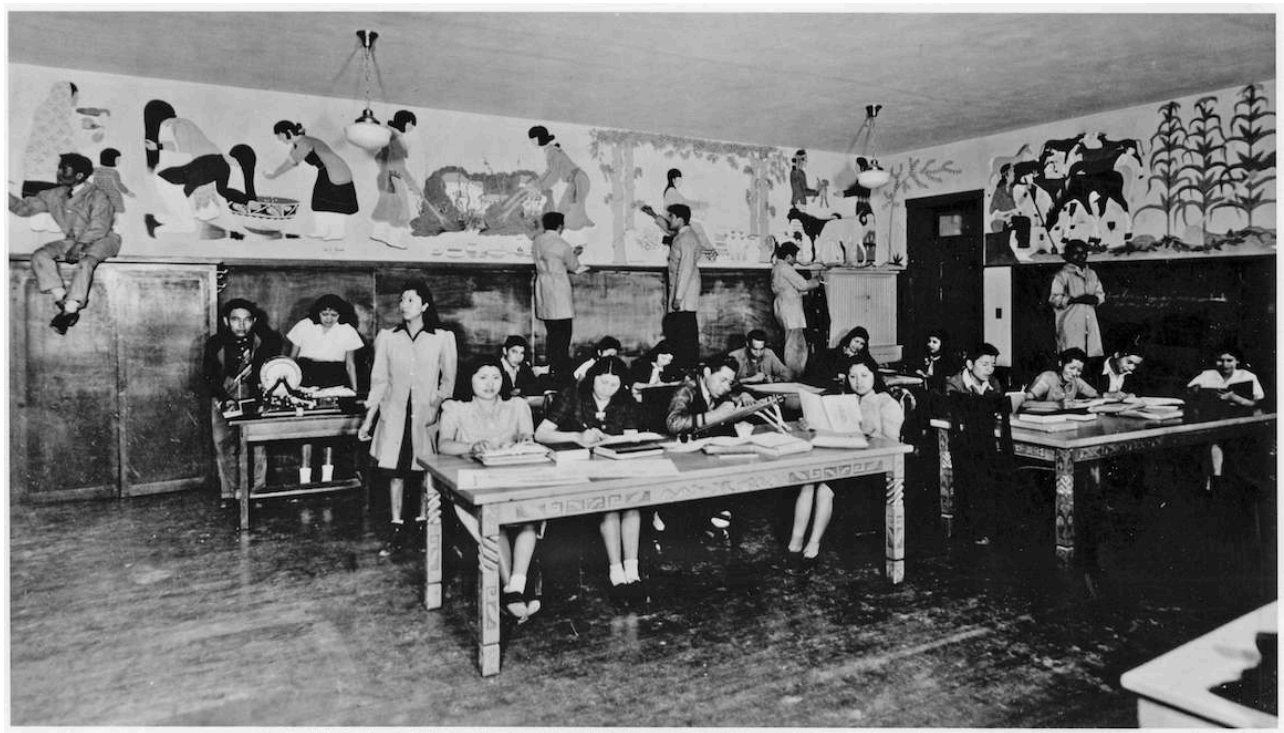

A social science classroom featuring murals painted by the Studio School students, 1935. Photograph by Ernest Knee; Courtesy of Palace of the Governors Photo Archives, NMHM/DCA, Neg. 30934.

The makers of posters were among the first Native students to study at the Studio School, a painting program which opened at the Santa Fe Indian School in 1932. <figure 2> According to a newsletter released in December of 1934, one month after Coze's visit, some 456 students were enrolled at the Indian School, ranging in age from adolescence to their early twenties, representing 41 tribes from around the United 
States (Tegayo 2). Dunn additionally reported that more than 150 students took classes in the Studio School during the academic year 1934-1935 (277). Their work built on the achievements of an established generation of Pueblo painters such as Fred Kabotie, Awa Tsireh (Alfonso Roybal), and Tonita Pena (Quah Ah) in New Mexico (Bernstein and Rushing; Brody 1971; 1997; McGeough; Penney and Roberts), and Kiowa painters such as Stephen Mopope and Spencer Asah in Oklahoma in the 1910s and 1920s (Wyckoff). Dunn worked to institutionalize the earlier, ad hoc developments by formalizing instruction, securing federal sponsorship, and growing an international market. While the Santa Fe Indian School offered training in a range of mediums such as pottery and textiles, the Studio School was unique in promoting painting as a modern fine art sourced entirely from Indigenous traditions.

Dunn's description of the last-minute request for posters harnessed the anti-capitalist rhetoric that framed Native modernisms in the wake of the Great Depression. She wrote,

The students were asked to make broader, sketchier drawings for this purpose; however, many of the paintings were as nice as those sent on for the exhibit, and all were superior works, entirely beyond ordinary poster quality. During the two days of intensive and joyous activity, most of the students on campus came at some time to the Studio to see what was going on, and some even volunteered to try to help. This one experience, perhaps more than any of the many inspiring activities in the Studio, proved absolutely that modern paintings, springing from Indian tribal sources, could be done wholeheartedly, spontaneously, and without thought of monetary reward. The students had cheerfully made paintings before to give one another, to the school and to take home, yet never had there been such an immediately voluminous outpouring of artistic effort as for this unseen and practically unknown cause. It seemed to be an unpremeditated gesture of international goodwill. (281)

Dunn's emphasis on the students' jovial naivety obscures the knowing manner in which they engaged with foreign text and by extension, new audiences. Construing their efforts as "without thought of monetary reward" stoked antimodernist desire for Native Americans to model traditional communal values that were threatened by industrial capitalism. She distinguished the students' work as finely-made gifts, in contrast to the crass commercial function of "ordinary" posters.

Dunn also spoke to the concerns of government reformers during the "Indian New Deal" of the 1930s. The opening of the Studio School heralded the temporary reversal of federal policies of assimilation that had dominated the national landscape for some five decades. Devastating losses of land, language, political authority, and ceremonial knowledge defined the reservation era, although not without substantial resistance from Native people. Some relief came when John Collier, Commissioner for the Bureau of Indian Affairs from 1933-1945, ushered in the Indian Reorganization Act of 1934. Although it was undermined ten years later, the new policy partially restored selfgovernance to Native nations and prohibited further allotment of their land (Deloria, Jr. 52-55). It also provided funding for economic development, including artistic and cultural ventures designed to support Indigenous self-reliance while bolstering New Deal nationalism.

14 As Jennifer McLerran has assessed, Collier's belief that "Native arts and crafts could help to construct a national identity through the establishment of an ancient and glorious past for America" (4) at once facilitated and elided Indigenous artists' engagement with commoditization and colonization (1). This widespread ideology 
came under fire by artists and scholars beginning in the 1950s. While many students recalled Dunn's kindness fondly, she was also criticized for corralling the heterogeneity of their approaches into the semblance of a cohesive "Indian style". Houser recalled, "[S]he trained us all the same way. 'You either paint like this, Mr. Houser, or it's not Indian art.' But what the hell, you have to have your own interpretation of things" (Highwater 149). His classmate, Oscar Howe (Yanktonai Dakota, 1915-1983), who participated in the poster commission before veering toward abstraction, famously wrote in 1958, "Are we to be held back forever with one phase of Indian painting, that is the most common way?" (Anthes, 2006 161; Anthes, 2018; see A52). ${ }^{8}$ The assumption of a romantic and assimilative uniformity continues to shape the memory of the Studio School, even as scholars have recently underscored the diversity and agency of the artists and works (Horton, 2016b; McGeough; Rushing, 2018 20-30).

Coze's appearance in this history prompts my reassessment of the Studio School through the lens of transatlantic performance culture. Answering Collier's invitation to visit New Mexico for the first time, the founder of the French boy scouts met the students in November of 1934. He promptly deemed their school "the Indian Rome where Indian art has been born anew!" (Tegayo 1). Coze published accounts of the meeting in two French magazines and in his book, L'Oiseau-Tonnerre: Paysages et magie peaux-rouges (385-391). In "L'Art sauvera-t-il les Peaux-Rouges?" (Will Art Save the Redskins?) in ABC Magazine d'art in 1935, the Studio School is posited as an agent of salvation. Coze issued a devastating critique of the historical politics of assimilation in the United States and lavished praise upon Collier, the "apostle of this renaissance." He supported Dunn's argument that the paintings spontaneously sprung from tribal traditions. Yet the text is full of lavish flourishes that border on the fantastical:

Reestablishing confidence gives birth to wonders. I spent several days at the government Santa Fe Indian School. In the immense studio, Sioux, Navahos, Pueblos, Apaches, Kiowas fraternize in their search for art. At their desks, young boys and girls tap into wells of unknown dreams to find curious figures who bound into being under their brush, without sketching, or at least rarely, without hesitation, without models, as if by looking deep within they can draw on their memory for the familiar gestures, the rhythm of sacred dances, and all the evocative images of a past which suddenly explode, as do the oil wells on the land stolen from the Indians.

Redskin Art Today! (“L'Art” 177)

16 Coze wrote with the flare of a circus master, transforming the students' brushes into magicians' wands that conjure "wonders" and "dreams" filled with "curious figures" that "bound" and eventually "explode" in a grand finale. His theatrical arc shifted Native modernisms away from the strict definitions of authenticity key to revivifying American nationalism and towards, I argue, a brand of knowing fantasy. Encouraging his readers to picture tempera paint exploding like an oil well, Coze drew attention to an exploitative system of capitalism that dispossessed Indigenous communities. Yet the effect was to heighten melodrama, not encourage political reflection. Immediately after, he translated the excitement into the exhibition title, "Art peau-rouge d'aujourd'hui !" His punctuation turned the pithy phrase into an advertising slogan. 
Figure 3
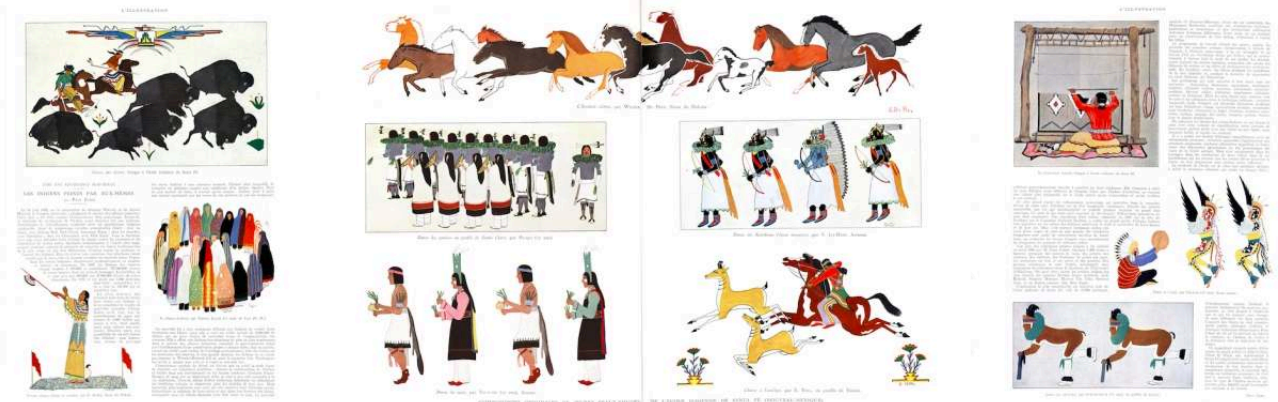

Paul Coze, "Les Indiens peints par eux-mêmes," L'Illustration, vol. 94, no. 4861 1936, p. 13-16. (www.lillustration.com)

17 Coze borrowed from the exclamatory immediacy of show business to direct French audiences towards an act in two dimensions on the Trocadéro. As the only known documentation of the paintings that were exhibited, his recolored magazine articles and book chapter are spectacles in their own right. In "Les Indiens peints par euxmêmes" (The Indians Painted by Themselves) in L'Illustration in 1936, thirteen-year-old Taos Pueblo painter Tonita Lujan's La Danse d'amitié (Friendship Dance) depicting two concentric circles of women clad in brightly colored striped and printed blankets, can no longer be read as a self-contained image. <figure $3>$ The unframed figures share the expanse of the layout not only with Coze's colorful text, but also with the mass of animals and riders sweeping across the top of the page in what he identifies as a "student mural." Chasse aux bisons (Buffalo Hunt) is actually a reproduction of a work by older, self-taught painter Ma Pe Wi (Velino Shije Herrera) from Zia Pueblo, who was invited to paint the walls of the Social Science Building when the Studio School opened in 1932. Elsewhere on the page the text wraps around a tall, slim, elaborately dressed woman, weaving her tightly into the graphic layout. Femme siouse offrant le calumet (Sioux Woman Offering the Pipe) raises her feathered instrument in a ritual that is equal parts diplomatic and orchestral; the point is made explicit on Howe's signed poster, where a nearly identical figure points her pipe directly at Coze's name. ${ }^{9}<$ figure 4> Turning the page, a herd of multi-colored horses, rows of Pueblo dancers, bounding antelope, and a mounted Plains hunter chase each other across the centerfold of the magazine. Here, the unbounded white space common to most early Native American paintings was used to suture the panoply of human and animal figures to Coze's words -and by extension, the world of his imagination, where specific cultural referents merged into the colorful tangle of a variety show. 
Figure. 4

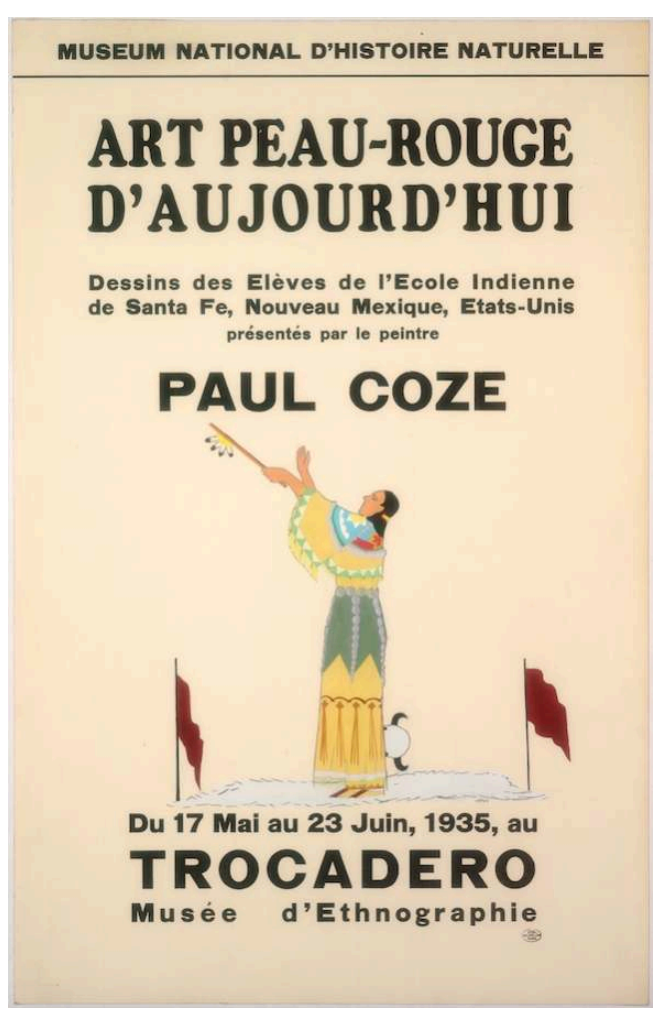

(A52) Oscar Howe (Yanktonai Dakota, 1915-1983), poster announcing Art peau-rouge d'aujourd'hui, 1935. Tempera on paper, 20 in. x 13 in. Courtesy of Muséum national d'Histoire naturelle; ( Inge Maresh.

While Dunn appealed to Americans invested in autochthony, Coze addressed French readers familiar with frontier mythologies from the transnational entertainment industry. When Coze led his scouts and hobbyists to perform "rodeos de cow-boys" and "danses Indiennes," he restaged Plains imagery popularized by Buffalo Bill Cody's Wild West and Rough Riders of the World, which employed Lakota families to tour France in 1889 and 1905-1906 (Burns, 2018a; Kasson 83-91; Jonnes). <figure 5> Coze also attended rodeos during his trips to the United States and Canada-a pastime apparently appreciated by an unnamed Studio School student, who designed a striking poster featuring a bronco unseating a rider. <figure 6> Only the man's airborne chaps, boots, and one flailing arm are visible behind the horse's arching body and red saddle. The rider's hat tumbles toward the "Trocadero" [sic], Coze's chosen arena, as if poised to land on top of the " $\mathrm{T}$ ". The artist may have witnessed a similar scene at a rodeo in the United States and embellished the memory with slapstick humor. ${ }^{10}$ As this example makes legible, Coze and the students shared a common western visual culture that could be translated into distinct sociopolitical milieus. 
Figure 5

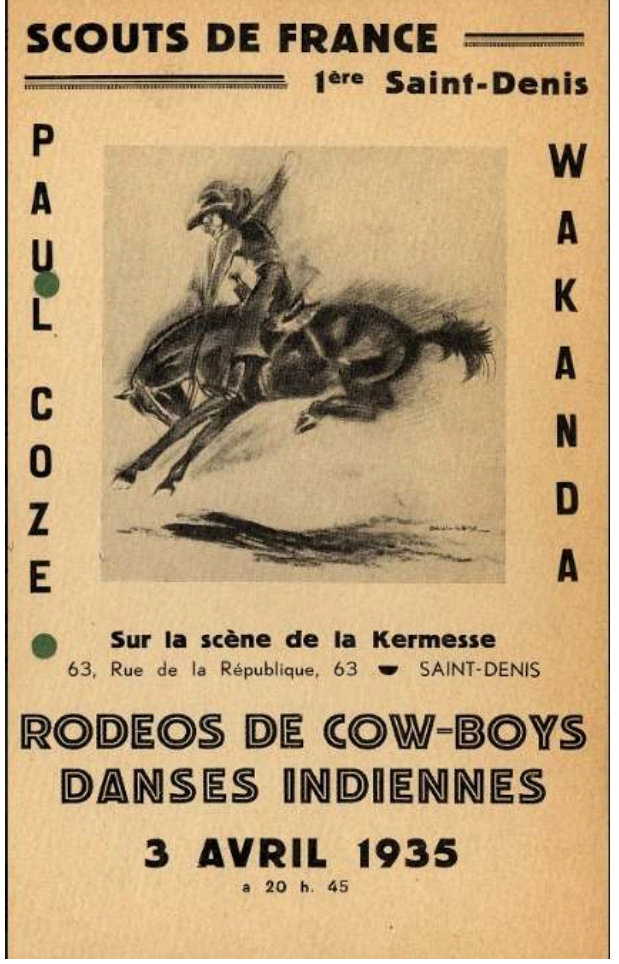

"Rodeos de cow-boys, danses indiennes," event announcement featuring artwork by Paul Coze, 1935. Courtesy of Patrick Bertrand. 


\section{ART PEAU-ROUGE D'AUJOURD'HUI}

Dessins des Eleves de l'Ecole Indienne de Santa Fe, Nouveau Mexique, Etats-Unis presentes par le peintre

\section{PAUL COZE}
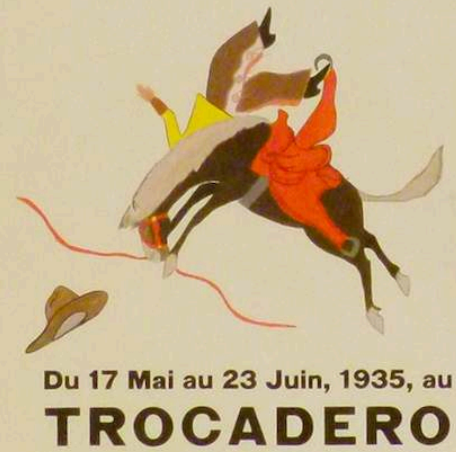

Musee d'Ethnographie

(A28) Artist Unknown, poster announcing Art peau-rouge d'aujourd'hui, 20 in. x 13 in., Inst-205. Gift of the Toyota Motor Corporation, 1992, courtesy of the IAIA Museum of Contemporary Native Arts, Santa $\mathrm{Fe}, \mathrm{NM}$.

Dunn shunned the influence of "magazine and book illustrations, posters, calendar scenes, catalog illustrations, caricatures, literal portraits, chromo mural and easel paintings, and the overpopularized 'Indian heads' and 'Noble Redman' scenes," yet this readily available source material crept into many of the posters (254). This was perhaps most true for artists who traveled to New Mexico from distant communities, as their cultural referents tended to be less stable than those of their Pueblo and Diné peers. Yet Ignacio Moquino (Waka Yeni Dewa, Zia Pueblo, 1917-1982), one of only five artists who signed extant posters, chose to depict a mostly naked horseman in the midst of spearing a buffalo-a scene that is largely of colonial provenance. ${ }^{11}<$ figure $7>$ Prior to Indian removal, Pueblo people traveled to the plains to hunt buffalo, and the memory of this practice persists in annual dances. Moquino's scene nonetheless shares elements with those by European and American artists, who romantically equated Native hunters with their horses by inaccurately picturing them wearing only loincloths or headdresses. A prominent example is Albert Bierstadt's The Last of the Buffalo, which was displayed in an art gallery window in Paris in 1889 (Burns, 2018a, 62; Burns, 2018b). $<$ figure 8> Moquino anchors the action in Zia Pueblo's agricultural cosmos by including three cornstalks sprouting from a horizontal vine below. Transformed by colonization, his is nonetheless framed as an Indigenous West. 
Figure 7

MUSEUM NATIONAL D'HISTOIRE NATURELLE

\section{ART PEAU-ROUGE D'AUJOURD'HUI}

Dessins des Eleves de l'Ecole Indienne de Santa Fe, Nouveau Mexique, Etats-Unis presentes par le peintre

\section{PAUL COZE}

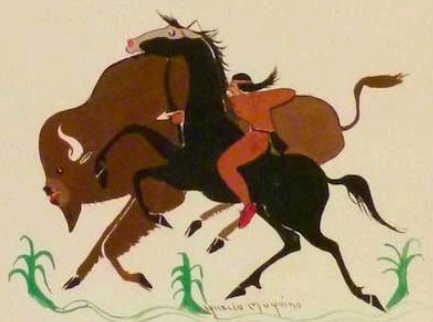

Du 17 Mai au 23 Juin, 1935, au

TROCADERO

Musee d'Ethnographie

(A47) Ignacio Moquino (Waka Yeni Dewa, Zia Pueblo, 1917-1982), poster announcing Art peau-rouge d'aujourd'hui, 1935. Tempera on paper, 20 in. x 13 in., Inst-224. Gift of the Toyota Motor Corporation, 1992, courtesy of the IAIA Museum of Contemporary Native Arts, Santa Fe, NM.

Figure 8

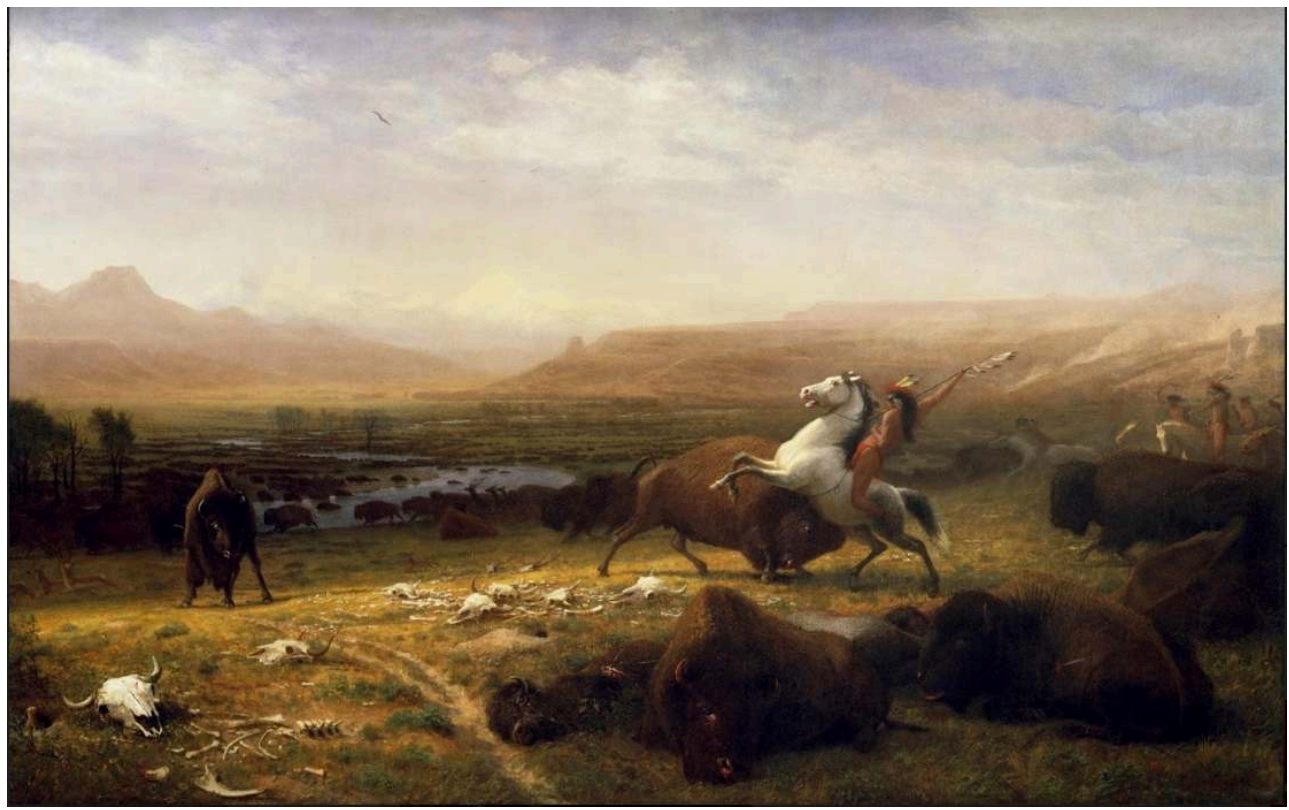

Albert Bierstadt, The Last of the Buffalo, 1888, oil on canvas, 180.3 x 301.63 cm., National Gallery of Art, Washington

Houser's galloping rider likewise navigated the commercial landscape of the twentiethcentury. His well-known biography helps to contextualize the artistic choices that he 
shared with many unnamed Studio School colleagues. < figure 9> The artist was born on a farm in Oklahoma in 1914, following the release of his parents and other resistant Chiricahua Apaches from a twenty-seven-year prison term at the hands of the United States government (Rushing, 2004 32-34). He recalled, "We had a kerosene lamp out there on the farm and I would sketch horses, people, dogs, motorcycles, race cars, airplanes, and things like that. I didn't have much of a traditional Indian background" (Rushing, 2004 13). Houser's absorption of family narratives, as well as inspiration from books and magazines, led him to imagine vivid scenarios he never witnessed in person. The artist related,

[Dunn] would say, "Do something from the ceremonial dances of your tribe." Well, I couldn't do that so easily, because I came from the farm. That meant I had to create more, use more imagination. I thought of what my dad used to tell me. I was really familiar with some of the oldtimers who went through war with Geronimo [...] Then I recreated the scenes in my art, imagining them as if they were happening right then while I was drawing or painting. (Perleman 112)

While older relatives offered oral stories, popular culture provided visual props. The headdress worn by Houser's rider was an honor intended for high-ranking men from select Plains nations who earned each feather. But thanks to Wild West shows and print culture, the war bonnet came to stand for Native people everywhere. In two additional unsigned posters, feather-crowned, portrait-like "Indian heads" of the sort discouraged by Dunn appear as central design elements (see A18 and A31).

Figure 9

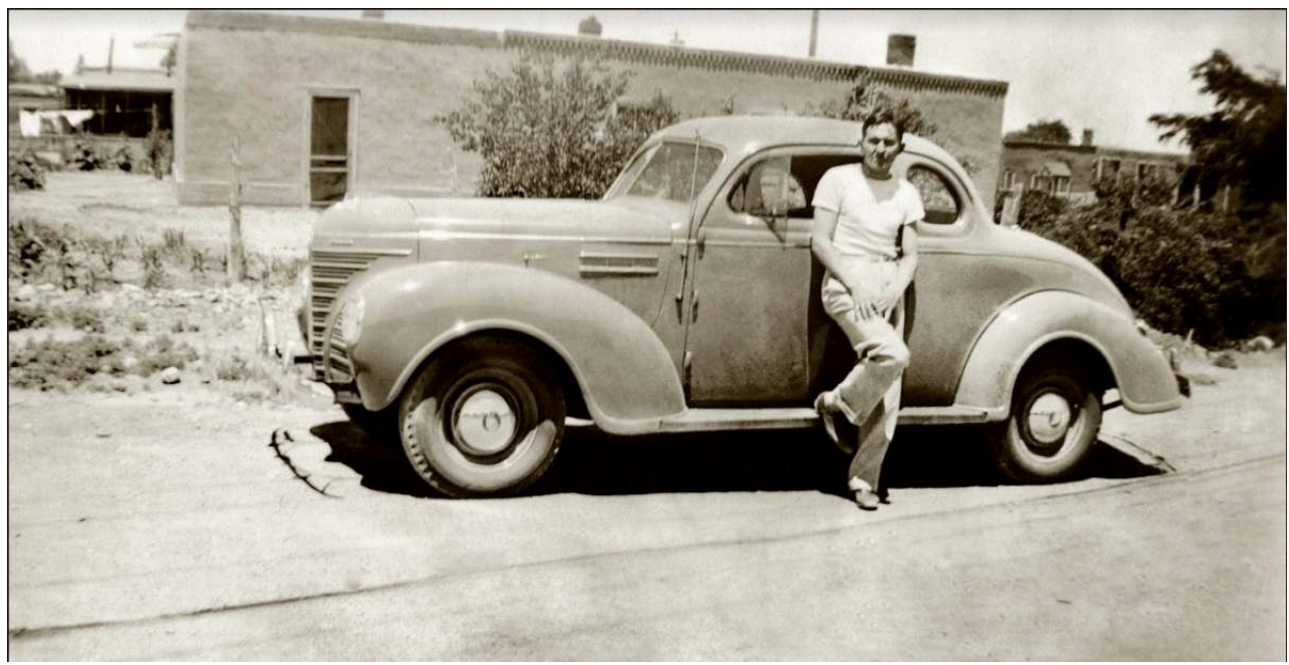

Allan Houser outside his house in Santa Fe, c.1938. Photographer unknown. Allan Houser artworks ( Chiinde LLC, Allan Houser Foundation archives.

Framed by Coze's theatrical sensibility, the poster commission put pressure on a paradox that existed at the Studio School from the beginning. Dunn's expectation that the students arrive with "a fund of knowledge about tribal custom and ceremony" was, for many, a fantastical standard (305). The school was born out of decades of colonial displacement, assimilation, and struggles for tribal sovereignty; the path to the past was circuitous. Accordingly, the students regularly turned to popular culture cues, "oldtimers"' stories, the work of admired peers, and their own imaginations to generate the proof of origins that she sought. The posters furthermore attest that the artists occasionally ignored Dunn's dictate in order to roam freely in subject and style. 
Coze, a consummate bricoleur, granted creative license to their wanderings and directed the outcomes toward new bodies and spaces abroad.

\section{From Studio to Street: The Ludic Art of Posters}

Figure 10

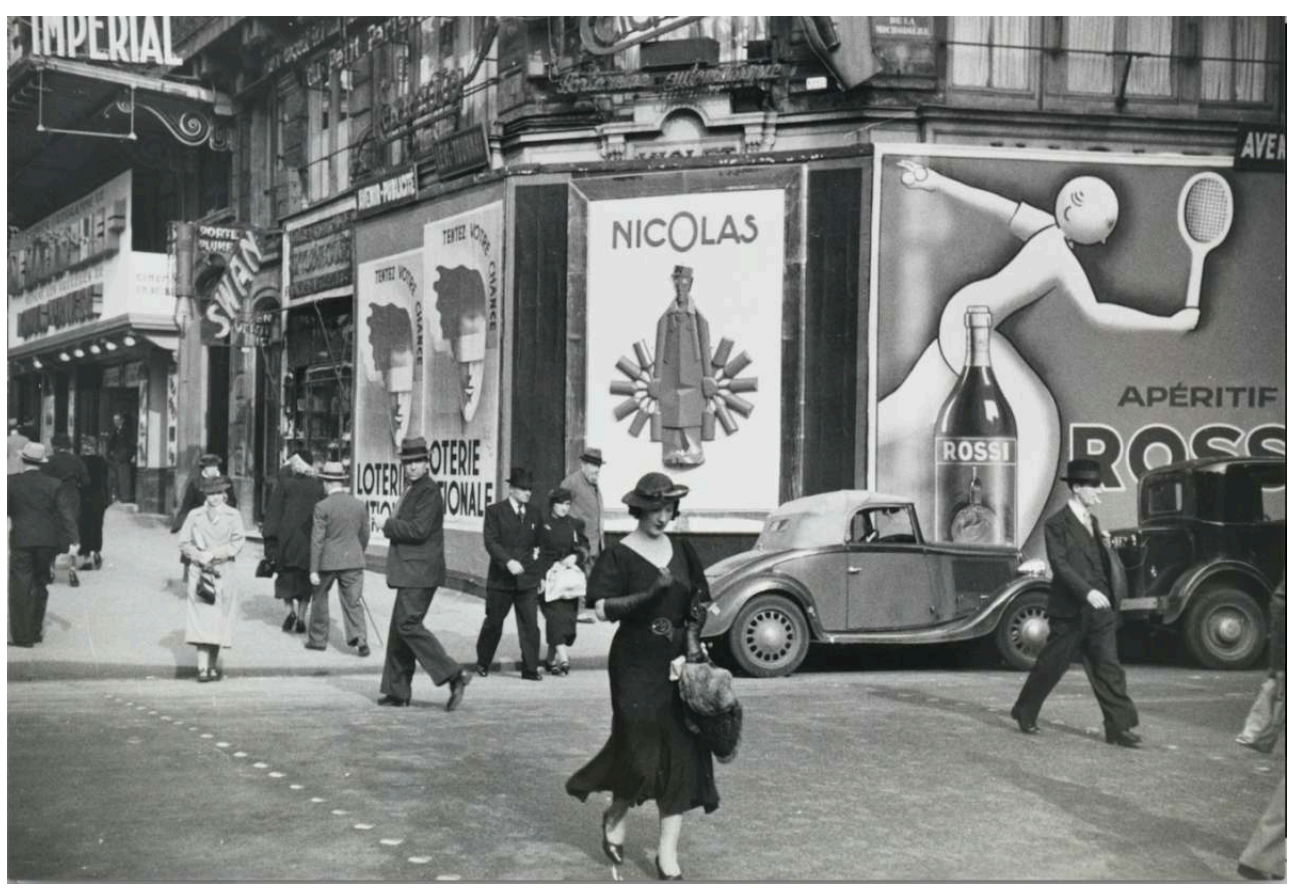

Parisians walk past lottery and vermouth advertisements in 1935. Photograph by Maynard Owen Williams, National Geographic Image Collection 668261.

Freed of the specific demands of bolstering American identity, the French poster commission introduced a number of distinctive challenges. In Poetics of the Poster, David Scott argued that the internationally popular form of the poster was aligned with modernist investigations into the hybrid potential of text and image. While the poster format was hardly new, neighborly relations between pictures and words gave way to new entanglements in the first decades of the twentieth century. Scott explained that by exchanging characteristics or locations, "word and image follow a double logic, one that is both syntactical and pictorial, textual and visual" (13). This new "rhetoric of the poster" had everything to do with its advertising function. To seduce a passerby to first look, then identify, remember, purchase and/or visit, image-text collaborations had to deliver messages with an economy of means that matched the accelerated pace of urban life and stole attention from the clutter of competition. <figure 10> Scott discussed this seduction as a game that draws a viewer into a play of image-text associations, testing her cultural savvy through punning, metaphor, metonymy, or contrast. It is by offering this "ludic pleasure that the poster draws from the observer a certain commitment to the message" (14).

The egalitarian relationship between word and image was complicated by the two-step production of the Studio School posters; first, the printed French text, then the handpainted picture. The layout of the text also predetermined its separation from the image to come. Lines of letters framed a conspicuous swath of unarticulated space in 
the center of the page, as a pointed directive to decorate, here. In this way, the text declared a certain authority over the image, not unlike that which Dunn attempted to exercise over Native students and Coze marshalled in his hobbyist circle abroad. Temporal and spatial disunity was compounded by a material differential: while repetitious printed text signaled what Walter Benjamin famously called the "era of mechanical reproduction," linking it to the advent of photography, cinema, and the commodity form, tempera paint clung to the aura of the singular mark (221). Combined with recognizably Indigenous imagery, painting risked confirming arguments by Dunn, Collier and others for an authentic, anti-commercial art with ties to the past. Finally, there was a foreign language challenge. As it is unlikely that many of the Studio students were fluent in French, the savvy so integral to the success of advertising images was tested by a gap in translation. Were the students able to play the seduction game while distanced from French text that had already claimed its priority on the page? Could such seemingly disparate forms be reconciled on the same plane?

The feathered lance held aloft by Houser's bareback rider hints at some students' will to work across temporal, spatial, material, and linguistic gaps. The thickness of the object is designated by two parallel brown lines punctuated by feather forms, which meet to form the tip of a lance. From even a short viewing distance the lines cohere into a single, bold, straight dash. Still visible at the front end is a soft pencil marking likely laid with the help of a straight-edged device. While the lance underscores Coze's name just above, it also echoes the black line that bisects the page at the top of the poster. No longer does text corral the image; now, painted and printed lines work together to frame the text. Borrowing from the logic of the surrounding graphics, the rider at once occupies his space on the page and conceptually moves upward, into the printed field. But of course, the lance cannot leave the rider behind, or he would go to hunt empty-handed. Instead, it marks a frontier where foreign text and painted rider converge. It is the pictorial equivalent of what Mary Louise Pratt has famously termed a contact zone, a social space "where cultures meet, clash, and grapple with each other, often in contexts of highly asymmetrical relations of power" (34). If, as others have established, colonial authority was exercised over Studio School pupils, the painted products of the classroom are key to understanding how the students met, confirmed, contested, or teased the authority of those frameworks. In Houser's figure, the lance sutures word and image to claim equal priority for the latter. In this way, belated paint met print on its own terms.

The regular appearance of such borderline elements in the extant posters indicates the students' pictorial savvy when faced with unfamiliar signs. While a detailed study of all sixty-one objects is beyond the scope of this essay, my chosen examples underscore common strategies that the students employed to wrestle with the constraints of the central image space. Many artists composed elements that mimicked the printed letters and lured them out of line. In an unattributed painting, the edge of a yellow tipi flap aligns with and nearly touches the vertical length of the L in Paul Coze's name, effectively extending the geometry of the text downward and into the triangular color field. <figure 11> A spray of black sticks protrudes from the opening on top, forming a sharp $\mathrm{V}$ that entices $\mathrm{L}$ and $\mathrm{C}$ to dip from their rigid location into the representational elements below. 
Figure 11

MUSEUM NATIONAL D'HISTOIRE NATURELLE

ART PEAU-ROUGE D'AUJOURD'HUI

Dessins des Eleves de I'Ecole Indienne de Santa Fe, Nouveau Mexique, Etats-Unis presentes par le peintre

PAUL COZE

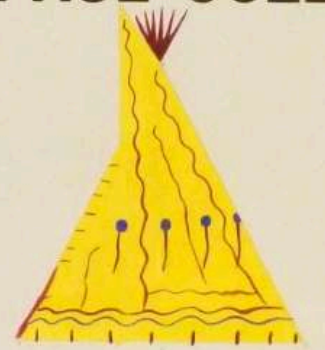

Du 17 Mai au 23 Juin, 1935, au

TROCADERO

Musee d'Ethnographie

(A41) Artist Unknown, poster announcing Art peau-rouge d'aujourd'hui, 1935. Tempera on paper, 20 in. $x$ 13 in., Inst-218. Gift of the Toyota Motor Corporation, 1992, courtesy of the IAIA Museum of Contemporary Native Arts, Santa Fe, NM. 


\section{ART PEAU-ROUGE D'AUJOURD'HUI}

Dessins des Eleves de l'Ecole Indienne de Santa Fe, Nouveau Mexique, Etats-Unis presentes par lo peintre

\section{PAUL COZE}

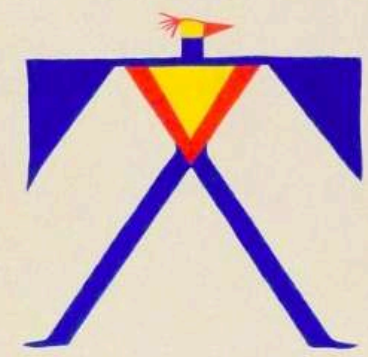

Du 17 Mai au 23 Juin, 1935, au

\section{TROCADERO}

Musee d'Ethnographie

(A23) Artist Unknown, poster announcing Art peau-rouge d'aujourd'hui, 1935. Tempera on paper, 20 in. $x$ 13 in., Inst-200. Gift of the Toyota Motor Corporation, 1992, courtesy of the IAIA Museum of Contemporary Native Arts, Santa Fe, NM.

In another case, the X-shaped frame of a stylized Thunderbird, a powerful spiritual being in Plains, Pueblo, and other Native contexts, holds up, in an architectural manner, a pair of outstretched triangles indicating wings. <figure 12> The vertical span in turn acts like a shelf precisely measured to the length of Coze's name, inviting us to imagine that the heavy letters might succumb to gravity and rest there for a bit. Further sympathy is generated between industrial and hand drawn lines when the painter disregarded the image frame entirely, attaching a crooked, bright red zigzag to the bottom of the horizontal black line that bisects the top of the page. This migratory strategy is evident in four additional posters (see A15, A19, A50, A58). Now, text can be read as a banner decorated with a swaying fringe-evidence of the double lives of letters, which regularly moonlight as images and objects. In turn, the prominent placement of the red line in the "sky" of the poster invites viewers to consider it pictographically (and meteorologically) as a symbol for the spiritually potent phenomenon of thunder and lightning. Returning to the v-shaped red beak and torso of the avian form below, even those uninitiated into Indigenous language and religion might arrive, via rebus, at the name of a sacred being: "tonnerre oiseau" (thunderbird) -notably used as the title of Coze's 1938 book, in which he described his first encounter with the students (385-391). ${ }^{12}$

Other students overwhelmed the text with compelling compositions that took up more than their allotted space. In a particularly striking example mentioned previously, the artist centered a representational profile with headdress inside of a circular "window" of bare cream paper, framed by bright abstract triangles in a symmetrical, interlocking 
motif. <figure 13> The jagged edges of the shape spread horizontally past the edges of the text, stretching toward the borders of the page. The vivid geometric mass fills the poster with jewel-like colors, rendering bold text suddenly diminutive. But the juxtaposition of the delicately rendered "Indian head" calls for a shift in viewers' attention, back to the cream surface of the paper and towards the intimate, detailed world of a miniature portrait. These cleverly managed shifts in subject, style, and scale are wholly engrossing, crowding out the comparatively banal act of reading words.

Figure 13

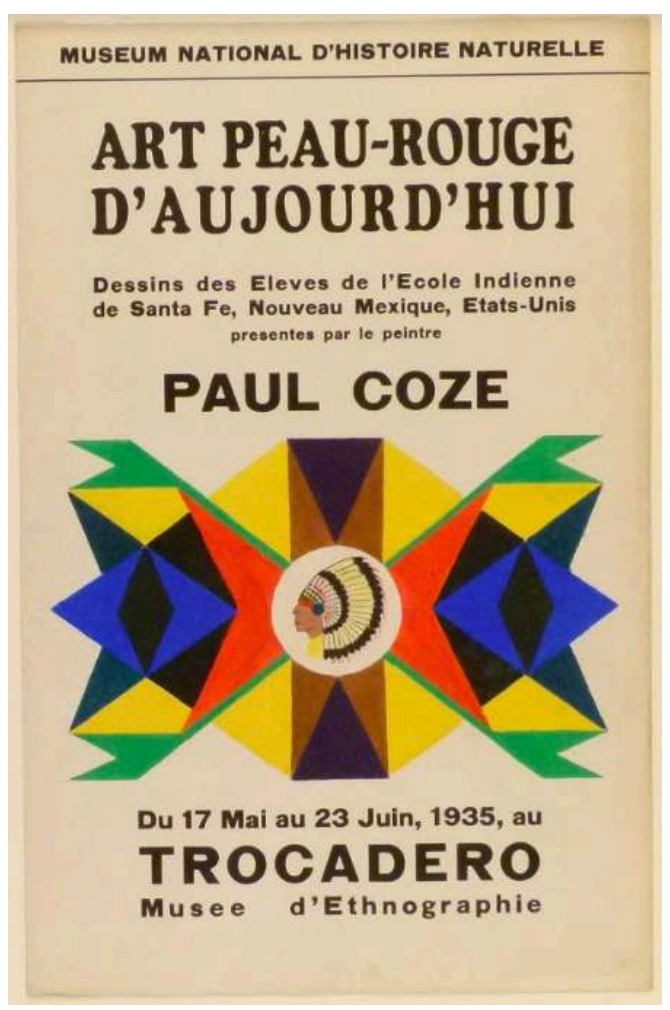

(A31) Artist Unknown, poster announcing Art peau-rouge d'aujourd'hui, 1935. Tempera on paper, 20 in. x 13 in., Inst-208. Gift of the Toyota Motor Corporation, 1992, courtesy of the IAIA Museum of Contemporary Native Arts, Santa Fe, NM. 


\section{ART PEAU-ROUGE D'AUJOURD'HUI}

Dessins des Eleves de I'Ecole Indienne de Santa Fe, Nouveau Mexique, Etats-Unis presentes par le peintre

PAUL COZE

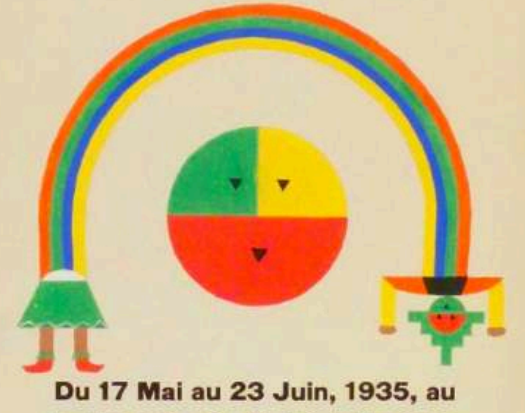

TROCADERO

Musee d'Ethnographie

(A51) Artist Unknown, poster announcing Art peau-rouge d'aujourd'hui, 1935. Tempera on paper, 20 in. x 13 in., Inst-228. Gift of the Toyota Motor Corporation,1992, courtesy of the IAIA Museum of Contemporary Native Arts, Santa Fe, NM.

In another such example, a sun motif is framed by the wide arc of a rainbow with head and feet articulated, suggestive of the guardian figures in Diné sandpaintings. ${ }^{13}$ Typically framing an opening in the composition toward sunrise in the east, the rainbow guardian assists in healing ceremonies that rebalance relationships between humans and the earth (see also A16, A20, A37). <figure 14> "Paul Coze" is balanced at the peak of the being's torso, while head and feet spill beyond the edges of the exhibition date just below. Although no part of the body touches the text, the rainbow seems to swell and push at the edges of the allotted space, hinting at the capacity of images to invoke forces that both inhabit and exceed their material composition. Precipitating an interplay of familiar and foreign elements, the artist articulated the relevance of Indigenous knowledge and aesthetics to a shared transatlantic modernity.

Faced with the possibility that the identity of Coze and "his" exhibition will eclipse that of the unnamed painters, this and other diverse maneuvers seem aimed less at overtly undermining authority than playing with the terms of its enunciation. Indeed, there is reason to doubt the signifying sway of the text over non-francophone painters who encountered the words first and foremost as graphic elements. Students could assuage the strangeness of the printed language by drawing its elements into their own games of visual punning. As images merged with text or pushed past it, the artists developed a visual language that enabled what Scott called a "reciprocal exchange" between disparate graphic and cultural elements. The paint teased the text's pretense to point elsewhere, to stand in for the "real" power of man or institution, while claiming space for additional meanings and unexpected relationships to unfold. 
Figure 15

MUSEUM NATIONAL D'HISTOIRE NATURELLE

ART PEAU-ROUGE D'AUJOURD'HUI

Dessins des Eleves de I'Ecole Indienne

de Santa Fe, Nouveau Mexique, Etats-Unis

presentes par le pointre

PAUL COZE

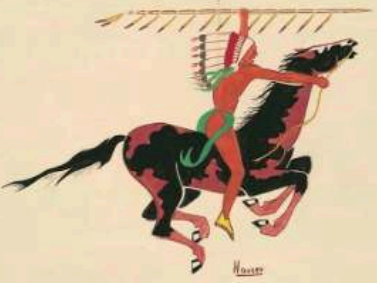

Du 17 Mai au 23 Juin, 1935, au

TROCADERO

Musee d'Ethnographie

(A1) Allan Houser (Chiricahua Apache, 1914-1994), poster announcing Art peau-rouge d'aujourd'hui, 1935. Tempera on paper, 20 in. x 13 in., Location unknown. Courtesy of the Musée du quai Branly, DA000199/32288 : Archives du Musée de l'Homme, Série C : Manifestations organisées par le MH 1930-1980. Allan Houser artworks @ C Chiinde LLC, Allan Houser Foundation archives. 
Figure 16

MUSEUM NATIONAL D'HISTOIRE NATURELLE

ART PEAU-ROUGE D'AUJOURD'HUI

Dessins des Eleves de l'Ecole Indienne de Santa Fe, Nouveau Mexique, Etats-Unis presentes par lo peintre

PAUL COZE

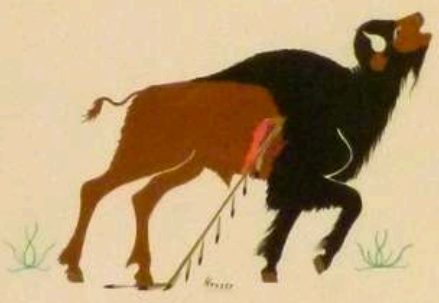

Du 17 Mai au 23 Juin, 1935, au TROCADERO

Musee d'Ethnographie

(A2) Allan Houser (Chiricahua Apache, 1914-1994), poster announcing Art peau-rouge d'aujourd'hui, 1935. Tempera on paper, 20 in. x 13 in., Inst-228. Gift of the Toyota Motor Corporation, 1992, IAIA Museum of Contemporary Native Arts, Santa Fe, NM. Allan Houser artworks @ Chiinde LLC, Allan Houser Foundation archives.

In their interactions with Parisians, Native artists were not limited to signs on a page. If, as a line, Houser's lance enacts a vertical relation to the text, as a representation it points in another direction. The rider holds his spear aloft at full gallop, aiming at a hypothetical object that lies beyond the edge of the page. Houser created an intentionally unfinished image that can only be completed with acts of imagination in the time and space of viewing. In this case, we can imagine the rider aiming his bow at the shifting milieu of the Parisian street, in a precise location now lost to us. But somewhere else in Paris a second signed poster by Houser continued the scene's unfolding drama. A large male buffalo with mouth agape lunges forward between patches of grass, a feathered spear protruding from a streaming wound in his side. Just as the armed rider begs the question, where is his mark?, the buffalo demands a reciprocal question, where is his hunter? <figures 15 \& 16> Houser united these components into a single frame in two known paintings completed at the Studio School in 1935, strongly suggesting that the two posters should be read as two halves of a whole. $^{14}<$ figure 17> By dividing the scene, Houser introduced a distinctive narrative component, implied in the suspension of the human rider with spear raised, punctuated by a cinematic cut between frames, and continued in the image of the pierced buffalo. One looks to the other for completion. When they traveled to France in 1935, the two episodes of the hunting event became temporally and spatially stretched across the landscape of Paris. It is a fate that Houser could have well imagined. I interpret his two-part scene as another visual game, in which a mobile, embodied viewer could only suture the two images through engaged acts of looking and 
recollecting. Here, text and image truly collaborate: print provides the repetitious element to jog visual memory, while paint tells the story.

Figure 17

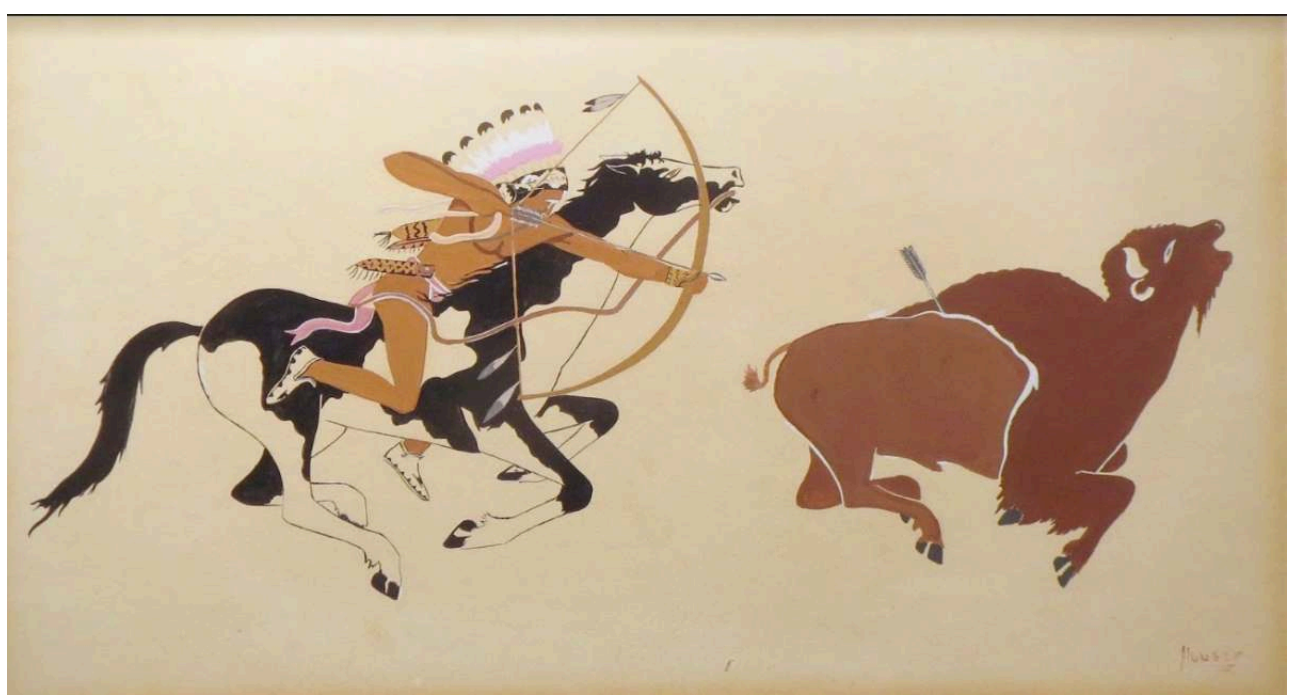

Allan Houser (Chiricahua Apache, 1914-1994), Buffalo Hunt, 1935. Tempera on paper. Allan Houser artworks @ Chiinde LLC, Allan Houser Foundation archives.

Cropped from their shared pictorial space by the abrupt edge of the page, horse, rider, and buffalo opened up to their real-time conditions of display by inviting any number of activities to transpire in the space between. While Scott's analysis restricted imagetext relations to the page, the posters comingled with other objects and bodies in crowded urban spaces. René Salanon has stated that "the street, in its vast open-air museum, offers to all the publics the endless vistas of pictures hung along its walls and fences" (n.p.). As André Breton, Walter Benjamin, and other period writers explored, the industrial cityscape jumbled past and present, high and low, near and far (Benjamin, 2002; Breton). With an eye for marvelous juxtapositions, Breton prescribed near daily walks for members of his Surrealist circle in the 1920s and 1930s. In the words of art historian Louise Tythacott, they wandered hoping "for unexpected, novel associations, for the discovery of objects torn from one set of circumstances and thrown into another" (37). In the jumble of windows and arcades, all that was "oldfashioned, broken, useless, almost incomprehensible, even perverse" in hierarchies of bourgeois taste were given new life through "chance encounters" with discerning viewers (Breton 52). Avant-garde writers and artists saw the assemblage of the streets as a form of everyday resistance to the capitalist imperatives of modern nation-states. They hoped to unleash a fantastical imagination in resistance to rationalized industrialization, by locating vignettes for an alternative framework of lateral, noninstrumental relations. Houser seems to have anticipated this varied landscape, and his horseman rode to meet it.

How might the posters have collectively shaped this urban environment? Their exact locations of display are unknown, but the pristine state of most of the extant posters, pricked by tiny pinholes, suggests that they were tucked behind glass, framed by surrounding print culture, commodities, and the reflections of curious faces. If, as I have described, the painted images played with the hierarchical authority of text on a 
vertical axis, they also interacted with an uneven field of social relations that unfolded horizontally in the streets. While period commentators emphasized egalitarianism, scholars have subsequently underscored that experiences of public space reflected asymmetries of gender, race, and class (D'Souza and McDonough; Wilson; Wolff). It is likely that some Parisians encountered the foreign imagery with an eye for racial spectacle, perhaps conditioned by the Mexican and Native stereotypes on the façade of the Jockey Café in Montparnasse. Yet, hinged to the French text and their varied surroundings, the painted figures closed an easy window onto antiquity or a distant frontier. We can imagine, furthermore, that they accrued power in numbers. Houser's memory game could be extended to the interplay of uniformity (text) and heterogeneity (images) among all the posters strewn across the city. The standardized words, while potentially controlling in relation to individual images, were relegated to a static support when viewed serially-like a marquee announcing the main act. ${ }^{15} \mathrm{Far}$ more arresting was the parade of painted figures that moved between them in the streets: drummers (A25, A53), dancers (A3, A7, A8, A9, A10, A17, A46, A50, A54), hunters (A1, A39, A47, A60), celestial beings (A4, A13, A43, A49, A51), and a lone bear (A36). The dynamic forms of play initiated by the students ensured that the posters were ready participants in the kaleidoscope of pedestrian Paris.

\section{From Street to Stage: Native Performances}

Figure 18

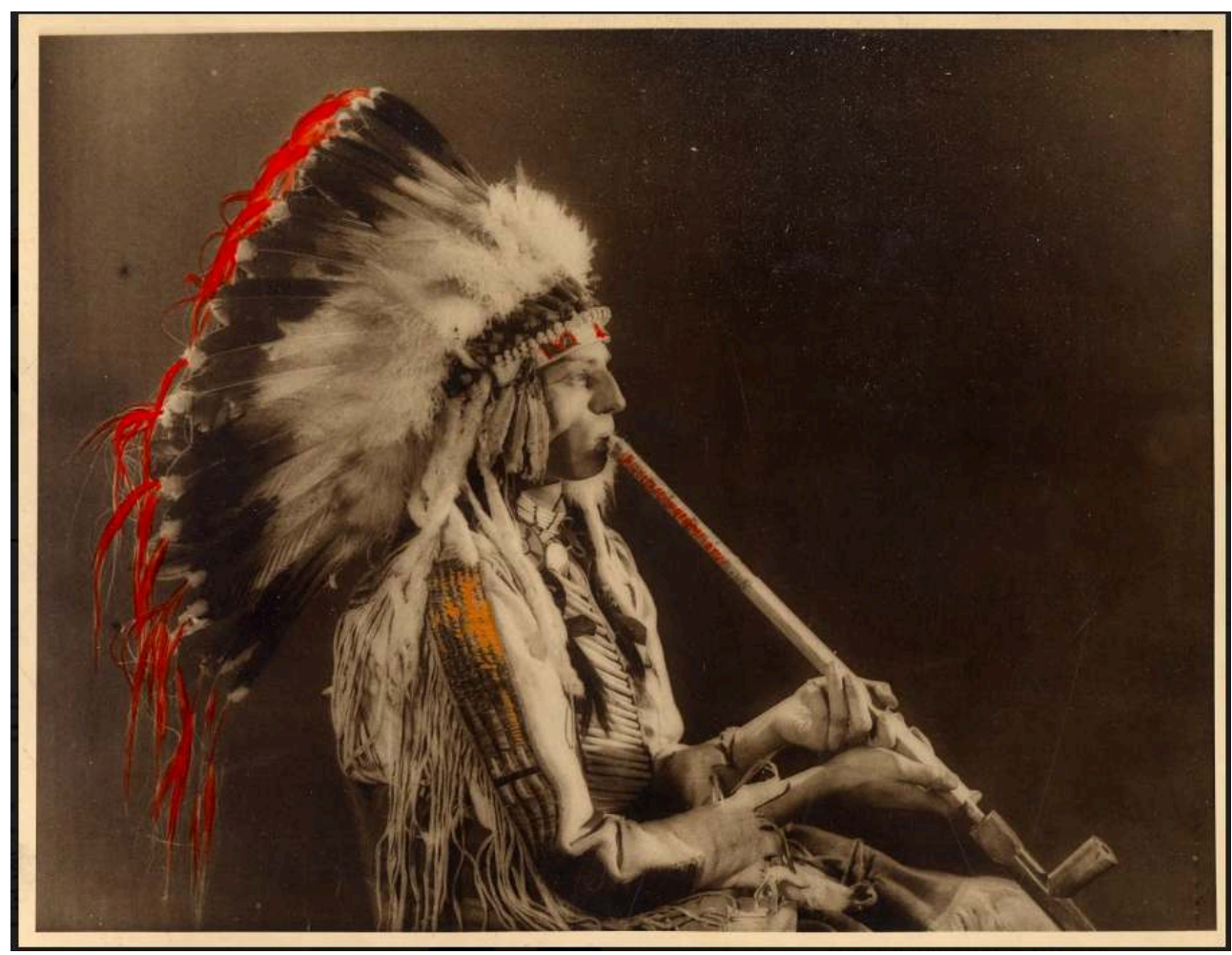

Hand-colored photographic portrait of Paul Coze, c. 1928. Photographer unknown. Courtesy of Patrick Bertrand.

Coze's multidisciplinary engagement with Native subjects helped to forge a continuous visual culture that connected the streets to nearby museums and stages. While he is 
little known in the United States today, many early twentieth-century Parisians would have recognized the designation of the bold black letters competing with paint at the center of the posters. Coze's voluminous efforts included books, essays, plays, concerts, films, dances, and exhibitions on Native North American themes and materials, in addition to his own Indian portraits on view at the Salon des Indépendants (DuBois 28-29; Peltier-Caroff, 2017a; Peltier-Caroff, 2017b). His presence was as large as his output. French writer Michel Droit described him as "of tall stature, with protruding cheekbones and an aquiline nose [...] He was able to sing exactly like [the Native North Americans], and when he dressed up to interpret some of their dances, the illusion was complete" (114). <figure 18> The painter assumed the identity of an ethnographer to complete his self-titled "Mission Paul Coze," a series of three trips in 1928, 1930, and 1931 to study, paint, and collect the oral and material culture of Cree, Saulteaux, Assiniboine and other Plains groups in western Canada. He turned his attention to the Indigenous Southwest in 1934, returning biennially and eventually settling in Phoenix in $1951 .{ }^{16}$ When abroad, Coze kept his francophone audiences in mind, writing of his encounters with Diné and Pueblo peoples beneath decidedly unscientific titles such as "Surprise-party peau-rouge." He carried home documentary notebooks, watercolor portraits, sound and film recordings, Indigenous clothing, and material culture to form one of the largest American Indian collections in France. ${ }^{17}$ While MET sponsorship validated Coze's collecting trips within the framework of ethnography, I will show that his unabashed embrace of hyperbole and fiction had significant implications for his Native associates, near and far.

These tendencies were already on view in Coze's exhibition, Peaux-Rouges d'hier et d'aujourd'hui, which opened at the MET in May 1931. The predecessor to Art peau-rouge d'aujourd'hui, the comparatively extensive displays surveyed material culture and Coze's own watercolors from his trips to western Canada. Parisians could walk among Native-garbed mannequins peopling tableaus of canoes, tipis and horses. A comparison of two installation photographs serves to underscore the theatrical nature of this purportedly "ethnographic" exhibition. <figures 19 \& 20> The first reveals a figure in headdress and hide clothing who raised a horse whip, establishing his role as a prophetic leader in a circle of five other blanketed and befeathered men. Ostensibly dioramic-the buffalo skull sitting on a ledge in the foreground makes the point-the close-up framing, narrative pose, and chiaroscuro lighting nonetheless transformed static figures into lively performers. A second photograph zooms out to show us the stage on which the action unfolded. <figure 20> The scene was housed in an alcove in the temporary exhibition walls, surrounded by comparatively staid framed images, hanging textiles, and glass cabinets filled with objects. A low step in front of the display breaks the spatial division separating theater from exhibition, inviting visitors to elevate themselves into the drama or conversely, imagine that the mannequin-actors might step down to walk among them. 
Figure 19

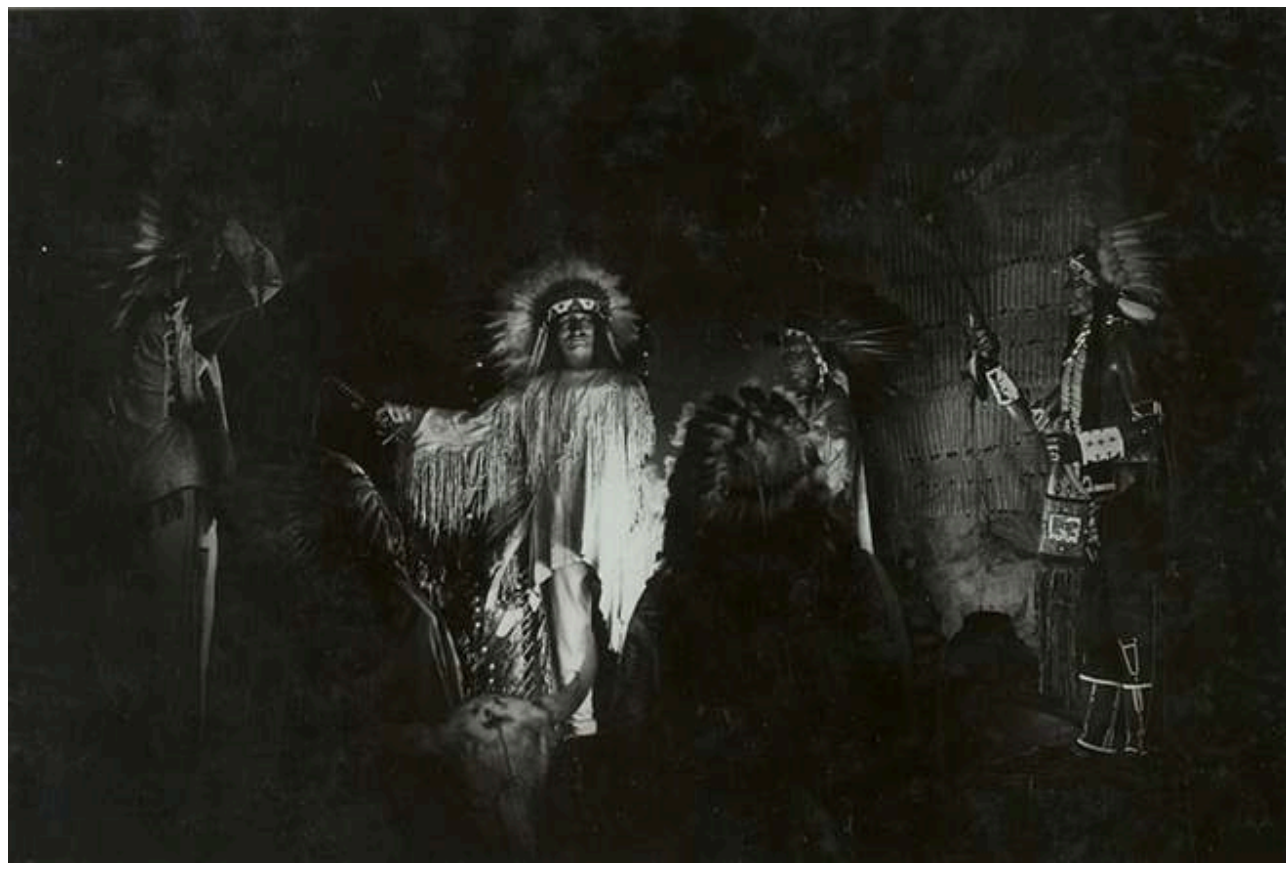

Paul Coze, View of a diorama of "a scene of a village with Indian chiefs." Peaux Rouges d'hier et d'aujourd'hui, 1931, Musée d'Ethnographie du Trocadéro. Photograph on baryte paper mounted on cardboard. $22.5 \times 29.5 \mathrm{~cm}$. (C) Musée du quai Branly, Paris, PP0004633.

Figure 20

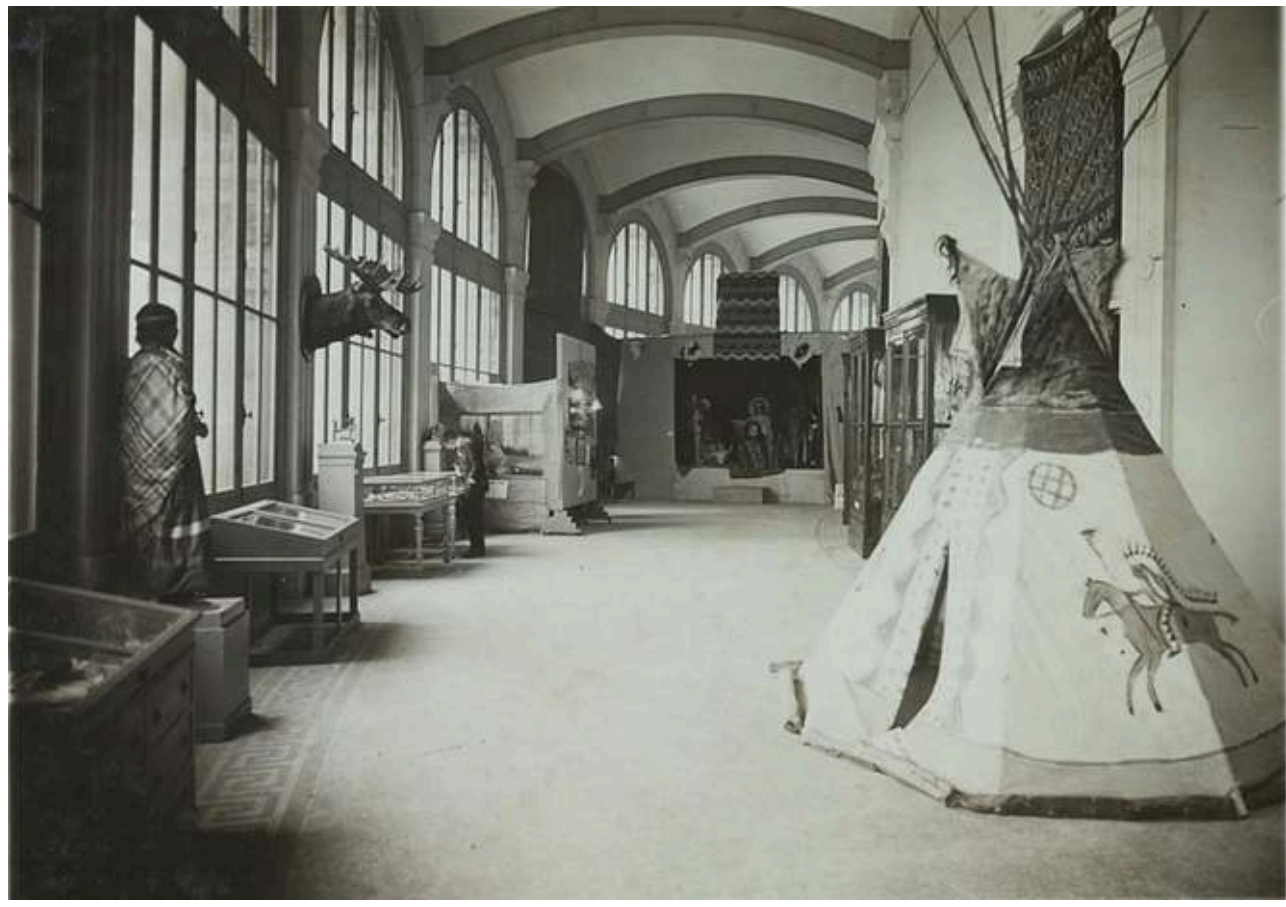

Paul Coze, Installation view of exhibition Peaux Rouges d'hier et d'aujourd'hui, 1931, Musée d'Ethnographie du Trocadéro. Photograph on baryte paper mounted on cardboard. $12 \times 16.5 \mathrm{~cm}$. C Musée du quai Branly, Paris, PP0001299.

36 An accompanying film that shared the exhibition's title purported to document Coze's Musée d'ethnographie-sponsored expedition to western Canada, "shot entirely on site 
and seeking above all to be 'true." The program for the opening night of May 30, 1932 at the Salle Pleyel in Paris nonetheless indicates that Coze employed Native men in Canada to stage scenes of wars, buffalo hunts and sweat lodges ("Peaux rouges"). In a private letter to his producer, the French director Jacques de Baroncelli, Coze revealed his willingness to fill in the gaps in the Canadian footage, promising that "in a few days in the studio with some Scouts and all the costumes and props that I possess, we can fake it" (Letter to Jacques de Baroncelli). He eschewed documentary truth claims altogether when writing and directing another Baroncelli project in 1934, a romantic drama featuring a Yakima performer, Charlie Oskomon, opposite Dao, an actress of Asian descent. While no known footage survives, a photographic still reveals Oskomon waving what appears to be a raven rattle from the Northwest Coast over the prostrate, bare-breasted body of Dao in the role of an "Indian princess." <figure 21> The exhibition and films were equally host to Coze's ample fictions. They set the stage for the entry of painted dancers and riders that peopled the companion exhibition, Art peau-rouge d'aujourd'hui, in 1935.

Figure 21

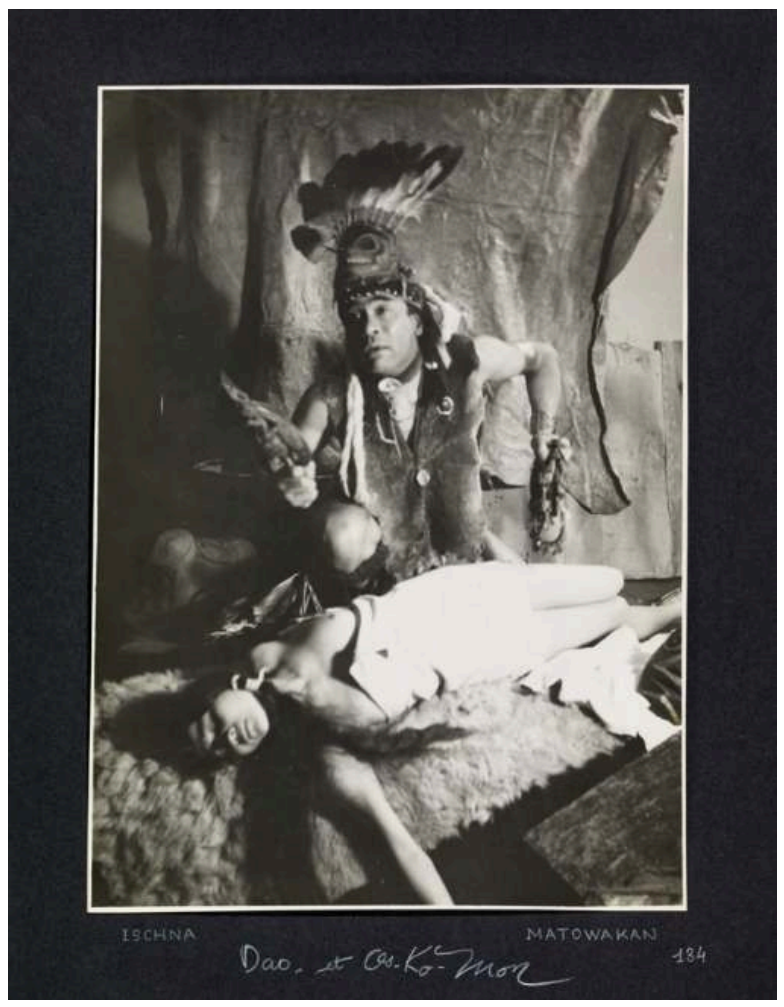

Anonymous, Photograph of Dao and Oskomon, respectively playing Ischna et Matowakan, (134), from the film Wakanda by Paul Coze, 1934. Photograph on baryte paper mounted on cardboard. (c) Musée du quai Branly, Paris, PA000514 34/70.2015.43.1.

Coze was always ready to join the act. Numerous photographs show the Frenchman dressed in iconic regalia he collected among Plains communities, including a regal eagle-feather headdress, a bone ribbed breastplate, and elaborately beaded hide pants and moccasins. To complete the identity of a Plains chief, he froze with a pipe raised to his lips or bow stretched ready to shoot an arrow. While dramatic studio lighting and heavy sepia toning could not mask his fair skin, Coze adopted an intense gaze that mirrored the stoic Indian poses conventional in period photographs. Philip Deloria, in a 
classic study of the long history of "playing Indian," linked adoption of stereotypical Native garb and other identity markers by Anglo impersonators to the strengthening of American national identity. Modern yearnings for authenticity and natural purity assuaged the rapid social, technological and political change that the country experienced in the twentieth century (1999 103). Speaking of the founder of scouting in America, Deloria wrote that "mimetic Indian play conferred a particular kind of authentic reality on Ernest Thompson Seton in his headdress and breechcloth," helping him to channel hard-to-access authenticity to the next generation of American youths (1999 121). Through communications with Seton, Coze modeled the French boy scouts after the Americans, channeling the primitivist ideals of hardy, outdoor survival to his young charges in Paris (Dubois 29). Yet Coze indulged a level of theatricality that shifted his Indian masquerades away from the strict definitions of authenticity key to revivifying American nationalism and toward, I argue, a brand of knowing fantasy.

His effusive personality notwithstanding, Coze was an agent of the broader culture of interwar Paris. In a famous speech at the Lycée Janson de Sailly in 1932, French writer Paul Valéry described a fundamentally contradictory landscape: "Never has humanity joined so much power and so much disarray, so much anxiety and so many playthings, so much knowledge and so much uncertainty" (140). Two years later, while the "playthings" prospered in the cabarets, cinemas, and circus, the streets of Paris became the staging ground for a veritable civil war. Riots broke out across the city in response to Republican government scandals and depression-era suffering. Although the violence peaked in 1934, suspicion, greed, and radical politics continued to split the country (Large 23-58). Notably, the culture wars of everyday Paris included widespread anxieties about rates of immigration from French colonial territories in Africa and the Caribbean. Critics and artists such as André Levinson and Paul Morand saw the explosive popularity of jazz as evidence of a dangerous rise of black subaltern power and the decline of "the European spirit" (Blake 86; 89). Often blurring the distinction between African American entertainers and African immigrants, French audiences interpreted Josephine Baker's gyrating, banana-ringed body at the famous La Revue nègre as an expression of the liberating or threatening barbarism of Africa (Berliner 1-3; Blake 85-6; 91-2; Burt 77).

Less frequent images of American Indians did not seem to provoke the same suspicions. The French relinquished the last of their colonial holdings in North America with the Louisiana Purchase in 1803 and largely turned their attentions to Africa and Southeast Asia. Amnesia ensued, permitting a cultural attitude of innocence towards Native Americans that anthropologist Renato Rosaldo has broadly termed "imperialist nostalgia" (Rosaldo 107-8). U.S. Indian removal and the establishment of reservations helped to produce a French discourse of pacified Natives, even as the stereotyped figure of the warrior was mobilized to new ends abroad. As Dominique Kalifa has explored, the name "Apache" carried connotations of resistance to normative civilization into the twentieth century in France. It was alternatively appropriated to denigrate criminal threats to the Republic and laud a home-grown brand of political radicalism (37). Notably, those attempting to wean the public off its dangerous jazz obsession promoted a waltz known as the "Apache" in the city's cabarets beginning in 1910 (Malnig 10). Borrowing from turn-of-the-century street gangs of the same name, the dance staged a violent encounter between domestic lovers or a prostitute and her pimp. In the 1920s and 1930s, the Apache was proudly lauded as a dance of Paris's 
"native savages" who were busy exploring the city's own wilderness, suggesting that the term became deeply entangled with constructions of interwar French nationalism (Blake 105). The conditions were ripe for Coze to imagine Paris as a liberating frontier for Native Americans suffering policies of confinement and assimilation in the United States-a vision that Native artists both claimed and bent to their own ends.

In particular, Indigenous performers seeking fame and reinvention abroad were willing to flatter the Frenchman's Indian antics. The celebrated Mohawk dancer Esther White Deer sent a telegram from New York in December 1934 that bore the message, "Wishing you a bon voyage depending on you to make me the star of paris let me hear from you soon heap much regards to oskomon" [sic] (Correspondence with Paul Coze). White Deer likely met Coze during her French tour in 1929 (Phillips 156), as well as Charlie Oskomon, a self-identified Yakima performer who came to Paris with a travelling circus that same year. When word of Art peau-rouge d'aujourd'hui reached New York in 1935, "Princess Atalie, America's Foremost Cherokee Prima Donna" (Atalie Unkalunt), an artist and founder of the Society of the First Sons and Daughters of America, crafted a letter to Coze full of insistent longing:

I have noticed by several papers that you planned the American Indian Exhibition of Art that now graces your Museum and city with posters of our native art, created by our boys and girls, mainly of the Southwest.

I can never begin to tell you how sorry I am because you did not have some of my art objects for such an exhibition [...]

Perhaps some future date will bring me to Paris as a concert singer and artist of my people. Now, it is to be regretted that I am not there, not only to sing the songs of my ancestors, but to assist you with interpretations of our art at the exhibition.

When you return to America, please call and see me at my wigwam in New York.

Aboriginally yours,

Princess Atalie (Unkalunt, Letter to Paul Coze)

41 While the Princess was angling for an invitation, the New York-trained Penobscot dancer Molly Spotted Elk (1903-1977) made her own way to Paris by dancing with the US Indian Band at the International Colonial Exposition in May of 1931. Dreams of the city preceded her. She wrote in her diary in New York in 1929, "If only one could dance solely for art! Maybe someday I will have that chance, if not in America, then in Europe" (McBride 128). A signed photograph in the Frenchman's personal collection, sent prior to her departure to Paris, bears the lavish compliment, "To Paul Cose, under whose fair skin there beats the heart of an Indian. -Molly Spotted Elk, 1930 [sic]." $<$ figure 22> 
Figure 22

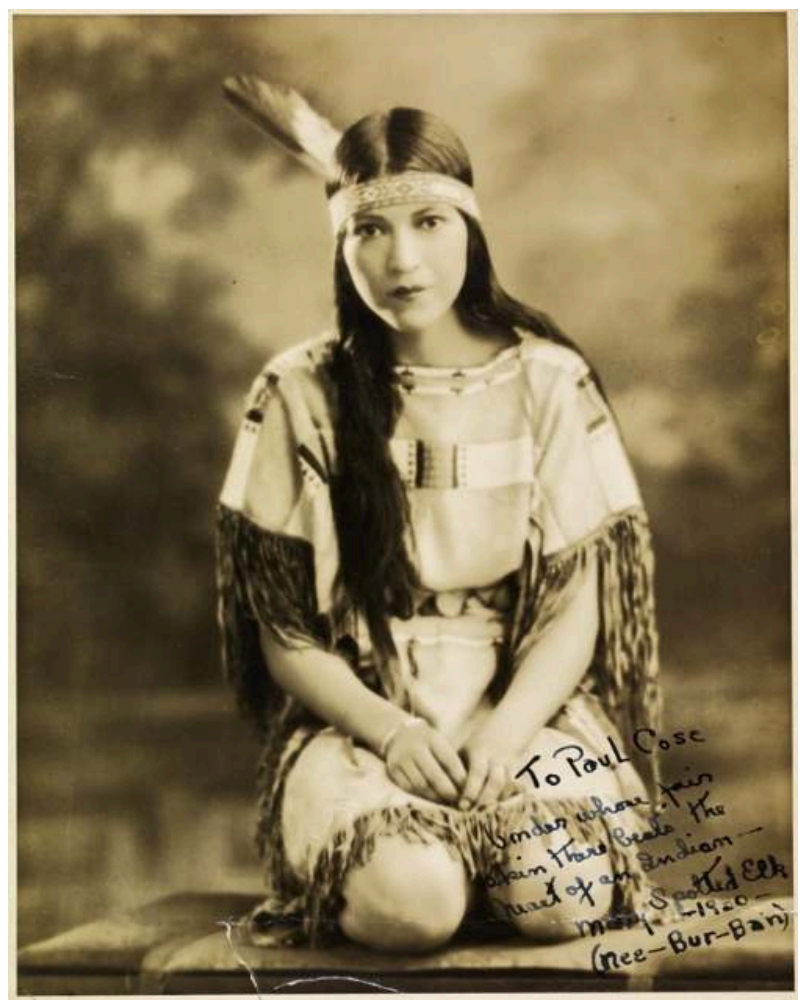

Hulcheraft (San Antonio, Texas), Studio portrait of Molly Spotted Elk kneeling, inscribed to Paul Coze, 1930. Photograph on baryte paper mounted on cardboard, $20,2 \times 25,3 \mathrm{~cm}$. (C) Musée du quai Branly, Paris, PP0215982/70.2015.43.3.

Coze found his most willing accomplice in Oskomon. The performer stayed on in Paris to become a prominent singer and dancer in Cercle d'études Wakanda, donning Coze's Indian collection and making public appearances with the boy scouts (Coze 1929). His career was managed and paid for by Madame Clement, a French composer enamored of "things Indian," and he lived comfortably in an apartment that Spotted Elk described as "big enough for a soirée" (McBride 165). But it was Coze, not Oskomon, who authored his biography:

It is natural enough, for an introduction, to begin like a Fairy tale [...] Once upon a time, there was in Paris a painter who [...] met an Indian the very day when this one was thinking of leaving Paris where he had just arrived. This Indian was Oskomon who, then in a circus, sang some American popular songs on horseback [...]

I remember the very first evening he came to my studio, I was just back from America and I asked him to sing the Indian songs which filled with musing thoughts the hours I had spent sitting near the camp fires.

Oskomon was abashed. He confessed he did not know anything about such songs. He had been too much used to hearing himself scoffed at for being an Indian in America, and it had been the same thing in Europe. Perhaps he did feel inwardly how shallow a jazz he was playing with himself, because white people had obliged him to do so. I did not make any speech to him. He found out quite by himself the awakening of his being.

One thing only perhaps helped with the beginning of what became his real life. That very evening, I took a tam-tam I had taken back with me, I gave it to him and I 
asked him to try and remember. [...] He took the tam-tam and never gave it back to me. But a few days after, when I saw him in a small room in which he lived in a hotel on rue Pigalle, I heard, from behind the door, that my tam-tam had found life again and that Oskomon's heart was already beating its old rhythm.

Oskomon began working. The sound of the tam-tam scared away the remembrance of his American education and gave birth again to the old Indian songs which had lulled his childhood. I advised him he should be only an Indian and never try to do what white people did. He soon showed he first was an interpreter, then a creator, and lastly an artist in his successes and even in his faults.

Paris seemed to favor him with its vivifying air, its curiosities, its intelligent sympathies, its artistic forces which make it the birthplace of art and the crucible of thought $[\ldots]$

The "Green Corn" soon attacked the Parisian Public in the manner of a genuine Indian War chief (Oskomon and Coze 8-10). ${ }^{18}$

Coze's sentimental "fairy tale" introduced a bilingual book of twenty-two poems published by Wakanda in 1936, illustrated by Coze, and supposedly authored by Oskomon. The poems bore titles such as "A Warrior," "Sacred Pipe," "The Life of a Navaho Blanket," and, perhaps most curiously of all, "Hopi Prayer at Sea." While it is unclear if Oskomon ever visited Diné or Hopi communities, it is certain that Coze knew well the differences between cultural groups in the land-locked Southwest and the coastal Northwest, where the Yakima reside. He must have assumed that his Parisian public wouldn't know these subtleties, or, perhaps more to the point, that they did not care. Oskomon was invited to the stage not to provide an education in authentic Indian identity, but rather to inspire the hopes and imaginations of a public inundated by "so much anxiety and so many playthings." Importantly, Coze's tale features contemporary Paris, not Yakima lands, as a central protagonist in Oskomon's nativist "return." In the midst of political crisis in France, the city's "vivifying air and intelligent sympathies" peeled aside his corrupt American education, inspiring his heart to begin "beating its old rhythm." <figure 23> Coze molded Oskomon's biography into a potent analogy for the durability of French society in the wake of economic turmoil and the spread of fascism. While culturally authentic Indians may have been a linchpin of American national identity in the same period, Coze recognized that the French were content to glean aphoristic meaning from their dealings with all things Native American. 


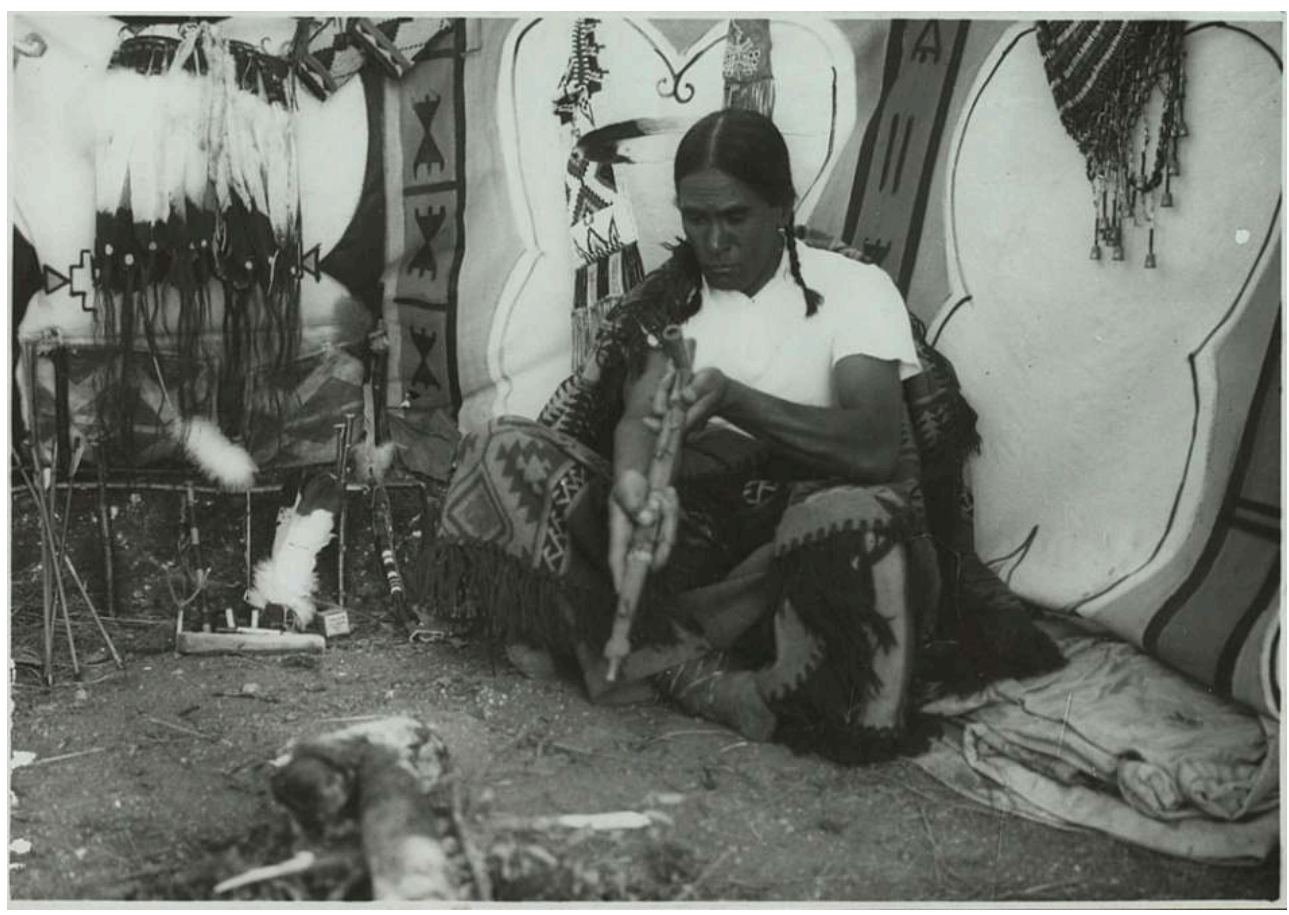

Paul Coze, Oskomon performing a pipe ceremony in a tipi, Wakanda, Paris 1932. Photograph on baryte paper mounted on cardboard, $22.5 \times 29.5 \mathrm{~cm}$. (c) Musée du quai Branly, Paris, PP0004811.

A rare gramophone recording of Oskomon singing "Chants Populaires Indiens" at the Université de Paris Institut de Phonétique in 1931 can give us a sense of what Parisians might have heard during an evening of performance. In "Ti-Pi-Lonesome (Chant d'amour)," Oskomon manages a baritone vibrato as he covers the Western musical scale punctuated by an occasional drumbeat. <audio 1> The English words "Oh my tipi lonesome" are mixed with nonsense syllables similar to jazz vocalists singing scat. Like the "Indian operas" popular in the United States in the early twentieth century, the song features what Deloria called "the sound of Indian." While much Indigenous music presented challenges to transcription because it did not conform to a Western musical scale, composers and musicians translated songs into a melancholic minor key for the stage. In this manner, they familiarized foreign sounds to meet the expectations of a non-Native audience accustomed to hearing opera and jazz (2004 183-223). "Chant de guerre," in contrast, forgoes melodic accommodation. <audio 2> Fast-paced drumming and rough-edged utterances of "heya" without a guiding key are punctuated by highpitched staccato yells. Two voices are evident on this track; the second, which chimes in solely to holler with abandon, is surely that of Coze. It seems that if "Green Corn" attacked the Parisian public "in the manner of a genuine war chief," the Frenchman was right at his side.

This media file cannot be displayed. Please refer to the online document http:// journals.openedition.org/transatlantica/11220

"Ti-Pi-Lonesome (Love Song)," Popular Indian Chants (Chants populaires Indiens), Chief Oskomon with Paul Coze, Université de Paris, Institut de Phonétique, Bibliothèque Nationale de France, Paris, AP2078, n. X 9093, 03 Face A. 
This media file cannot be displayed. Please refer to the online document http:// journals.openedition.org/transatlantica/11220

"War Chant," Popular Indian Chants (Chants populaires Indiens), Chief Oskomon with Paul Coze, Université de Paris, Institut de Phonétique, Bibliothèque Nationale de France, Paris, AP2078, n. X 9094, 04 Face B.

The duet by Coze and Oskomon is a performative counterpart to the posters. In the latter, the Frenchman's ubiquitous name similarly merged with the students' handiwork to play their parts in concert. The pre-printed posters functioned like a theatrical stage, on which the figures of hunters, warriors, and dancers moved and intermingled. Across Parisian streets, museums, magazines, circuses, and nightclubs, sights and sounds of "Indian" were heterogeneous and in motion. For Coze's Native associates, this proliferation of signs doubled as an invitation to participate in an expanded, elected set of relationships amid the physical and ideological confines of the reservation era.

\section{Spotted Elk, Surrealism, and Anticolonialism}

Just as Studio School artists subtly challenged Coze's authority using graphic strategies, the French context of reception involved conflicts over the authorship, form, and value of Native cultural expression. This is made abundantly clear in the case of Molly Spotted Elk, whose diaries offer a rare first-hand account by a Native person navigating the cultural scene of 1930s Paris. ${ }^{19}$ The performers in Coze's circle clashed with the Surrealists' critique of French colonialism, which unfolded through contemporaneous exhibitions of Indigenous material culture elsewhere in the city. More broadly, anticolonial activity was a part of the cultural landscape of Paris as well as in French colonies in the 1930s, begging the question of its relationship to the circulation of Native art.

51 The Colonial Exposition of 1931 was a fraught ticket to freedom for Spotted Elk. The sprawling six-month spectacle worked to convince over seven million visitors from around the world of the benign successes of France's imperial efforts, especially in Africa and Southeast Asia, while hiding the realities of growing political unrest in the colonies. Other participating nations, including the United States, similarly exercised their power over colonized subjects by staging veritable human "zoos," comprised of architectural renderings of Indigenous huts and villages. Ethnographic displays were augmented by programs of music and dance (McBride 153).

Instead of applauding Spotted Elk and the rest of the Indian Band, members of the Surrealist circle headed by Breton launched a vehement critique of the events. Members circulated two manifestos calling for a boycott of the Exposition and the "immediate evacuation of the colonies," joined forces with the Communist Ligue antiimpérialiste to stage a counter-exhibition, La vérité sur les colonies (The Truth about the Colonies), and distributed tracts in working-class, immigrant districts where anticolonial activity persisted underground (Morton 100; Stansell 117). The violence of World War I radicalized an international avant-garde, leading some to invert colonial hierarchies that posited Europeans as culturally superior to those they colonized (117-18). The Surrealists' approach blended opposition to bourgeois, capitalist French 
culture, desire to access alternative cultural and spiritual systems, and political support for those they deemed oppressed. Their agenda by definition excluded Spotted Elk, Oskomon, Houser, and other Native artists, who sampled from the very expressions of transatlantic modernity deemed suspect by avant-garde manifestos.

As Bunny McBride has emphasized, the Indian Band was called upon to demonstrate "the cultural progress of the Indians" (153) in keeping with paternalistic U.S. narratives embraced by Dunn at the Studio School. The sixteen male members played the Star Spangled Banner and popular jazz tunes wearing Plains headdresses and "full war paint" in front of a full-scale replica of Mt. Vernon (158). U.S. newspapers lauded the "picturesque" accompaniment of Princess Spotted Elk, "a university girl [who] interpreted in her dances [...] centuries of joys and sorrows of the Red Man" (156). She was "a pretty girl playing the tom tom" and "a dancer of great talent" (158). At once patronizing and admiring, the accounts suggest the contradictory array of stereotypes and opportunities offered Spotted Elk as she navigated distinct nationalisms on the brink of a new life abroad. In a lengthy account published in the Portland Sunday Telegram in 1931, she pointedly ignored the vestiges of U.S. colonialism that framed her participation, preferring to underscore the Exposition as "a tribute to the power of the French." She wrote ecstatically of her encounters with "the wonders of the world," which she found "dazzling, crude, bizarre, fantastic, grotesque, stately, modern and primitive" ("Beautiful Maine Princess"). The list of adjectives mirrored Coze's ready embrace of hyperbole and contradiction, while foreshadowing the hybrid performances and posters that would populate Parisian streets, museums, and stages in subsequent years.

Figure 24

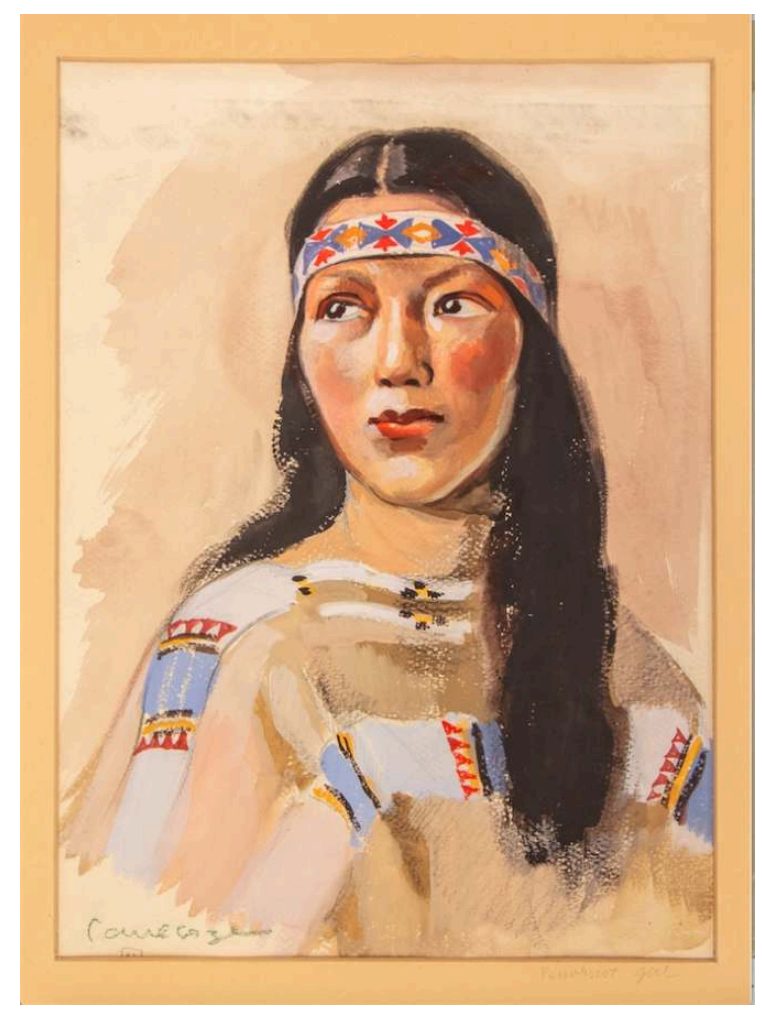

Paul Coze, Penobscot Girl (portrait of Molly Spotted Elk), c. 1930. Watercolor on paper. Courtesy of the Royal Alberta Museum, Indigenous Studies Program, H95.88.16. 
54 intellectual and creative opportunities afforded her unique status as a Penobscot woman among elite social circles at the height of artistic primitivism in Paris. She and Coze had already begun a friendship during his visits to the United States, which may have further influenced her decision to "gamble for a stake" by staying on in Paris after the Exposition closed. Coze asked her to pose for his watercolor portraits and in turn she wrote letters of introduction to friends in New York to help him find "American beauties" to paint (Letter to James Allen). <figure 24> Upon her arrival in Paris, she made several trips to the MET at Coze's request to give input on the final stages of Les Peaux rouges d'hier et d'aujourd'hui. Through Coze, Spotted Elk met the museum director Paul Rivet and his partner, the jazz socialite Georges-Henri Rivière, who continued to invite her input on museum exhibitions of Native American and African material over the next several years. Spotted Elk had her own reasons for visiting the institution, as she recounted fondly in her diary, "Even the sight of primitive things and real pictures of Natives does me good" (McBride 182). She was a regular attendee of French ethnographer Marcel Mauss's lectures at the Sorbonne, an authoritative invited speaker on Native American issues, a celebrated dancer with an entourage of French admirers, a budding novelist, and a fan of Josephine Baker, who she described upon meeting as "charming with oodles of personality" (179-180). She eventually married French journalist Jean Archambaud, about whom she wrote, he "never seems alien, or a white man [...] [W] hen [Johnny] loves a woman, it's regardless of color or creed (204). ${ }^{20}$ Along with affirming Coze's "heart of an Indian," she indulged Archambaud's penchant for dressing in Native garb and signing his love letters with a drawing of a wolf (206).

Spotted Elk's reception was undoubtedly shaped by romantic ideas about Native Americans, but in a framework where "Indian" had become so malleable as to permit her presentation as a multifaceted contemporary subject. She no longer complained, as she did in the United States, that she felt like an "Injun in the flesh parade" on stage (136). She initially appeared with Oskomon on programs touting "noted Indian artists, Chief Oskomon and Princess Spotted Elk," until her distrust of the man led her to terminate the partnership (165). ${ }^{21}$ Dressed in buckskins and braids, she performed her own inventive choreography, jazz routines, the Charleston, or variations of generic "corn" and "war" dances (McBride 187; Phillips 58). <figure 25> She also swapped sequences and costumes with women from India, Indonesia, and Malaysia who stayed on following the Colonial Exposition to become her friends and collaborators. Phillips has interpreted her remixed performances as "highly nuanced interventions" that ultimately destabilized period stereotypes, "rather than uncomplicated or even mercenary collaborations in the dominant culture's fictions of Indianness" (43). Spotted Elk's writings furthermore insist on a bifurcation of the "dominant culture" when she crossed the Atlantic. She resoundingly critiqued American racism while affirming the nationalist sentiments of her French hosts, for example by asserting in a Maine newspaper that Europeans "appreciate real expression and Indian art" (41). Like Oskomon, she responded to Coze's vaudeville-like approach to "Redskin Art Today!" and associated constructions of French nationalism as an invitation to sample and experiment with a repertoire of cultural forms. Her activities mirrored those of the Studio School painters, who hinged vibrant figures to the names of the Frenchman and associated institutions.

Transatlantica, 2 | 2017 


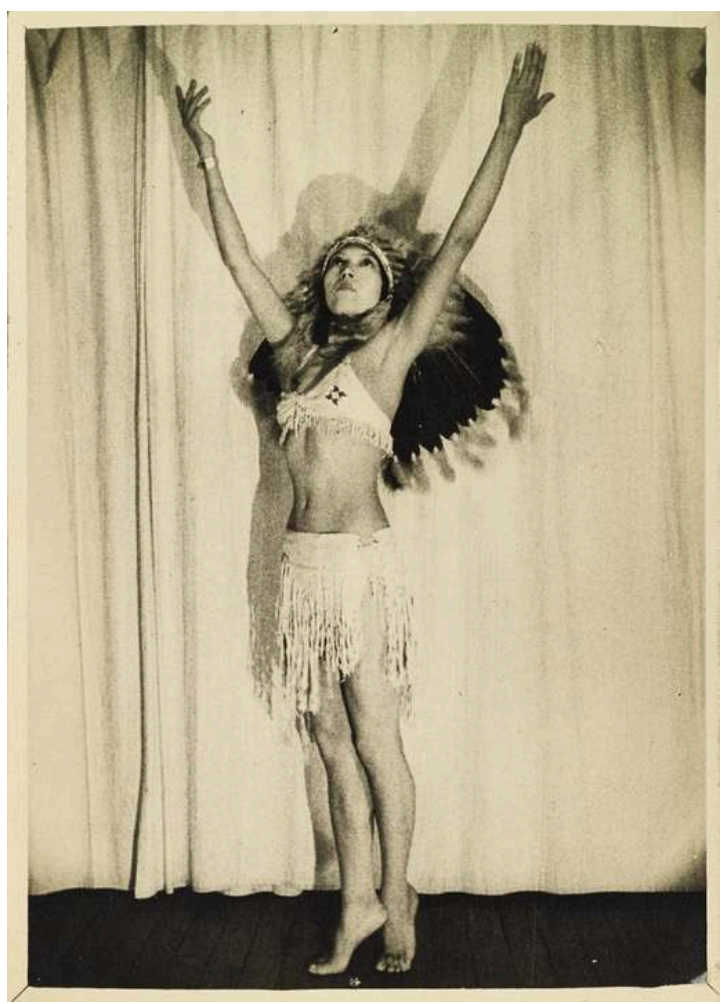

Godard, Molly Spotted Elk, 1928. Photograph on baryte paper mounted on cardboard (141). ( ) Musée du quai Branly, Paris, PA000514 42/70.2015.43.1.

Indigenous artists' embrace of such opportunities placed them at odds with the aesthetic and political program of the Surrealists, who were active in many of the same contexts during this period. While Native Americans did not figure into the Surrealist's immediate critique of French colonialism, their art was incorporated into an avantgarde valorization of marvelous objects that more often included works from Oceania, Africa and Mesoamerica. Although North American material culture was relatively difficult to acquire, Breton's circle read the reports of the Smithsonian Institution Bureau of Ethnology, cheaply available in French bookstores after WWI. In the early 1930s art dealer Charles Ratton exhibited rare Yup'ik and Northwest Coast masks that he acquired cheaply from the Museum of the American Indian in New York. Katsina tithu-small wooden carvings of spiritual beings given to Hopi children and, by the 1880s, made for sale to outsiders (Pearlstone)-could be found among the jumbled collections of the Trocadéro, augmented by collecting trips made by Breton, Aragon and Éluard to London. Prior to Coze's first trip to the Southwest, these figures appeared alongside Mesoamerican sculptures and contemporary paintings in Yves Tanguy et objets d'Amérique at the Galerie Surréaliste in 1927; by 1936, Native American carvings were fully integrated in the Exposition surréaliste d'objets (Cowling 66). <figure 26> In a Preface to the 1927 catalogue, Breton described the visual qualities of "dolls of New Mexico," writing, "In the crenellate headdress you find clouds on the mountain, in the center of this small checkerboard a little ear of corn; a rainbow around the mouth; in the vertical striations of the dress, the rain falling in the valley" (Maurer 547-8). In the expressive conjoining of wood, paint and feathers, Breton located a kinship with, and inspiration for, a Surrealist aesthetic that, in James Clifford's words, "values fragments, curious 
collections, unexpected juxtapositions" (540). The Surrealists admired the hybridity of old, exotic objects-so long as they appeared unsullied by Europe.

Figure 26

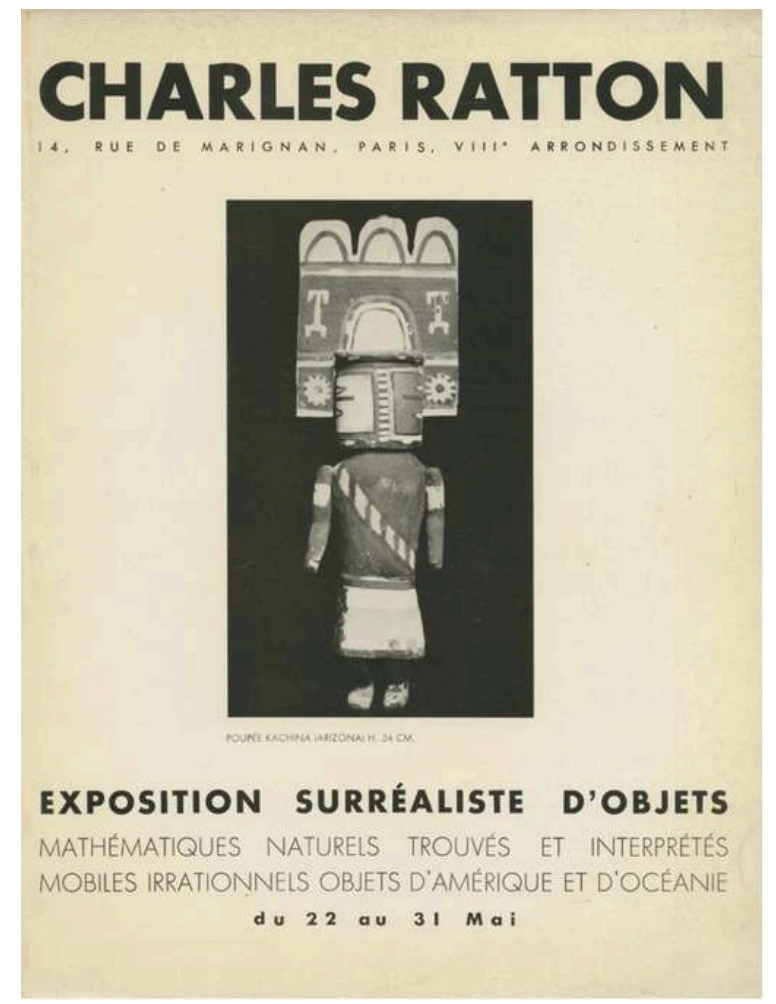

Advertisement for Exposition surréaliste d'objets featuring Hopi katsina tithu in Cahiers d'Arts, $\mathrm{n}^{\circ} 1-2$ 1936. Courtesy of Éditions Cahiers d'Art.

57 Like Coze, Spotted Elk, and Oskomon, the Surrealists-both members of Breton's circle and dissidents like Georges Bataille and Michel Leiris-participated in programs in and around the MET. Bataille wrote for the catalogue of the museum's first exhibition of Mesoamerican art in 1928, worked with Riviere to publish the interdisciplinary journal Documents, and attended lectures by Mauss at the Institut d'ethnologie alongside Spotted Elk. Among his multifaceted activities, Leiris accompanied the famous DakarDjibouti expedition (1931-1933) that culminated in an important exhibition at the Trocadéro for which Spotted Elk consulted (Clifford 544). At some point, the Surrealists must have seen Spotted Elk on stage or in Rivet's office, heard Oskomon's operatics in the halls of the Institut d'ethnologie, read Coze's theatrical word play in the mainstream l'Illustration, or stumbled upon a poster during a flight of flânerie. Although the ethnographic institutions acted as meeting halls for a diverse set of interests, Coze's circle and that of the Surrealists seemed to pass through different doors. Avant-garde artists and writers did not collaborate with Coze, nor embrace the work of the contemporary Native painters and performers he promoted.

I attribute their apparent disconnection to fundamentally incompatible visions of where Indigenous arts belonged within a broader story of colonial modernity. While the Surrealists' own aesthetic practices invited impure cultural mixing consonant with the streets and stages, their fetishization of colonized peoples' cultural difference led back to the trap of dualism they set out to avoid. Louise Tythacott joins other critics in 
arguing that they merely inverted, rather than destroyed, their own cultural conventions: "The devalued is revalued, but always in terms of existing European hierarchies of taste, place and position" (41). In their abhorrence of elite French culture, Breton's circle in particular constructed Native America as its antithesis, a spiritual refuge free of capitalist doctrine. The Surrealists thereby extricated their aesthetic sensibilities and political commitments from the density of colonial histories, which had long reshaped the cultures in question and occasioned the arrival of Native subjects and objects on their doorstep. This relegation of Indigenous arts to a space outside of industrial modernity echoed the impossible ideal of authenticity enforced by Dunn's curriculum and associated constructions of American national identity in the same era. Contemporary posters and performances-evidence of Native artists' associations with popular entertainment and the upper echelons of French societywere tainted by the very bourgeois culture that the Surrealists sought to escape.

Figure 27

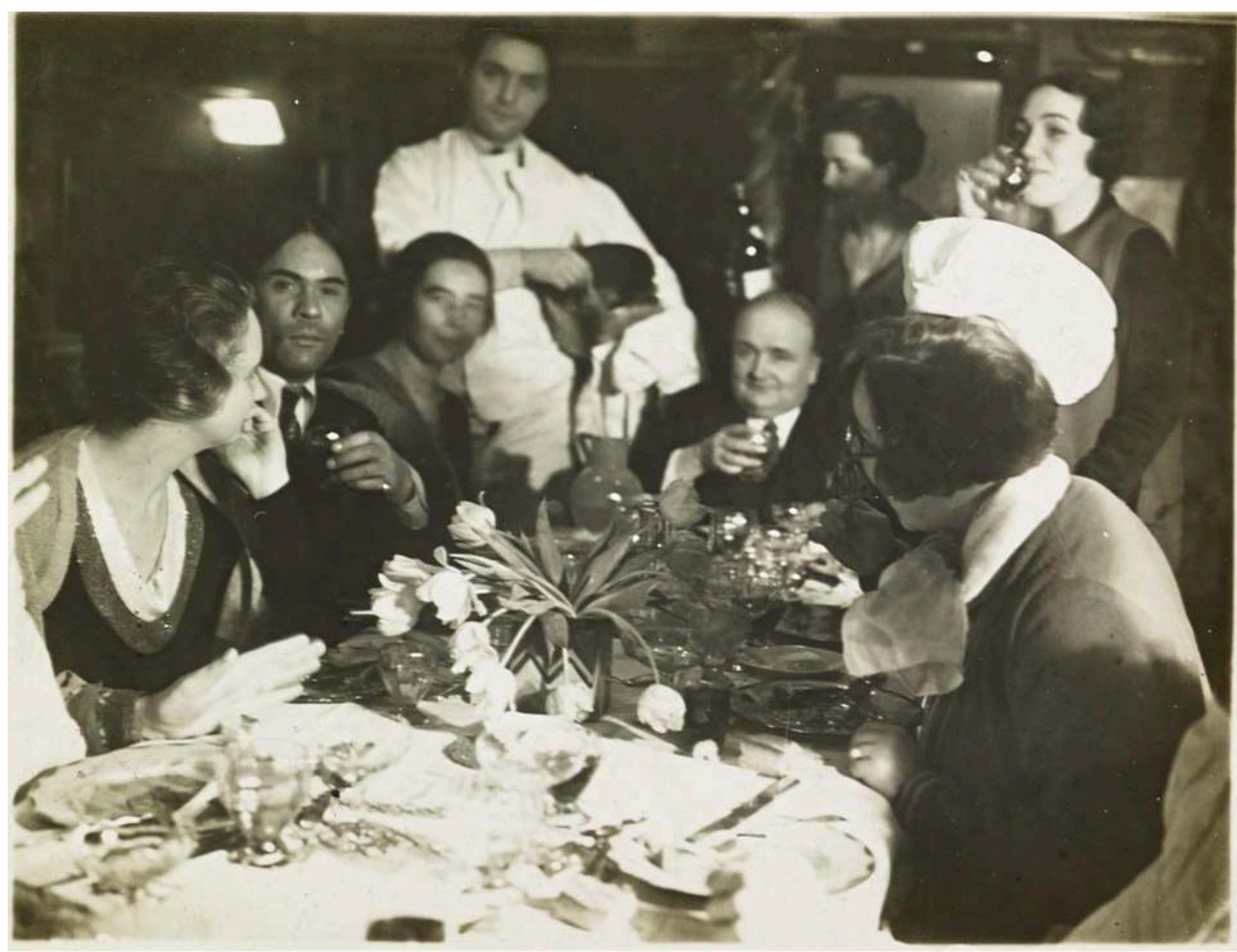

Anonymous, Oskomon among dinner guests. Photograph on baryte paper mounted on cardboard (109). (c) Musée du quai Branly, Paris, PA000514 08/70.2015.43.1.

Their loyalties rooted in patron circles and popular performance venues, neither Coze, Oskomon, nor Spotted Elk took a vocal stand against French colonialism. <figure 27> Indeed, Coze's admiration for Paris's "vivifying air and intelligent sympathies," Oskomon's dependence upon wealthy patrons, and Spotted Elk's affirmation of France as a refuge from U.S. racism indulged French nationalism in a manner opposed by the politically trenchant avant-garde. Still, when Spotted Elk performed the Charleston alongside a "corn dance," and Oskomon and Coze indulged a duet of war whoops, they reassembled incongruous signifiers in a manner akin to a Surrealist collage (Adamowicz). Likewise, when the makers of posters sutured imagery of tipis, headdresses, hunters, and dancers to the French text and the flux of urban Paris, they 
engendered a provocative form of play normally associated with the radical agenda of the Parisian artistic elite.

As this study of posters and performances with Coze's name attached has revealed, there was more room in interwar Paris for Native artists as contemporaries, present and actively shaping the cityscape, than Surrealist manifestos suggest. This was perhaps most true when such evocations fell outside of France's immediate colonial purview, and did not directly challenge the country's increasingly fragile grasp on international power. Despite Coze's outspoken critiques of federal Indian policy and history, the Studio School painters saw few overt professional or political returns from the poster commission. While performers such as Spotted Elk and Oskomon competed for refuge and reinvention in France, the painters were pressed to navigate an altogether different political climate shaped by U.S. colonialism, including legacies of Indian removal, assimilation, and New Deal reform. Nonetheless the students' will to stretch a variety of enclosures-from Dunn's paternalistic curriculum, to Coze's outsized name, to the strictures of avant-garde primitivism-is made palpable in the poster commission of 1935. By teasing the borders of text and paper with paint, they claimed the entangled spaces of a city that most would never see. By reconnecting the painters and performers in Coze's far flung circle, we can trace "a sense of the Native presence in early twentieth-century art history" (Phillips 29) across a dichotomy of static images and mobile bodies. Indigenous artists traded forceful anticolonial critique for a capacious creative arena, operating within, yet pushing the edges of, a modernity that had yet to make room for both.

\section{Coda}




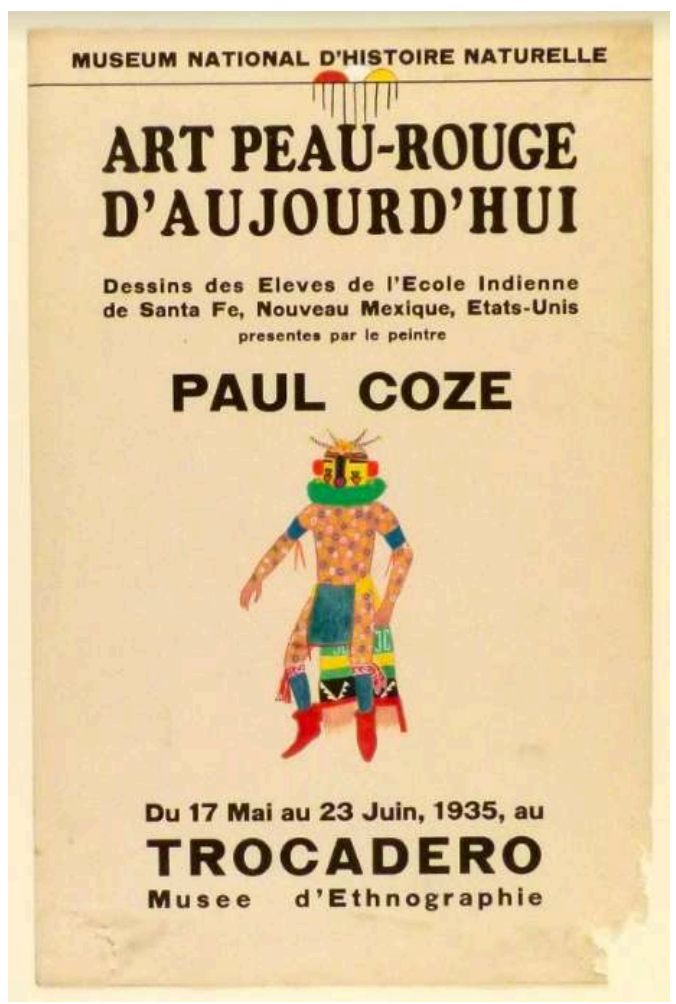

(A50) Artist Unknown, poster announcing Art Peau-Rouge d'aujourd'hui, 1935. Tempera on paper, 20 in. x 13 in., Inst-227. Gift of the Toyota Motor Corporation, 1992, courtesy of the IAIA Museum of Contemporary Native Arts, Santa Fe, NM.

61 The "dolls of New Mexico" admired by Breton were imbued with the power of Katsinam, benevolent beings who visit the arid mesas of the Hopi homeland in northern Arizona for six months each year. As the Hopi painter Fred Kabotie explained, they embody "the whole thing, nature. Even the spirits of little birds and ants [...] [T] hey are the messengers between the Hopi and the very high natural powers, like the clouds and the sun and even the moon and stars" (Seymour 122). By honoring these visitors in prayerful ceremonies, public dances, and art, Hopi people ensure not only an abundant harvest to sustain the community, but "good will and prosperity to all people of the earth" (Secakuku 112). Following the arrival of railroads, tourists, anthropologists, and other agents of colonization in the nineteenth century, Hopi artists were challenged to translate the values and sensibilities associated with Katsinam into artworks exhibited on both sides of the Atlantic (Horton, 2015; Pearlstone). ${ }^{22}$ In one surviving poster, a figure in regalia appears to advance across the central image space. <figure 28> Though diminutive in size, the bent knees and outstretched arms of the spotted corn Katsina suggest a dancer in motion.

Like other Studio School peers, the unidentified artist did not limit the design to the space between lines of text. Instead, she attached a tricolor cloud motif to the "horizon" of the printed black line at the top of the poster, echoing the stylized depictions of landforms and weather found on Pueblo pottery. The curve of a white semi-circle at the center of the motif pushes like a pillow against the bottom of the "Hi" in "Histoire," while the longest of the black vertical lines signifying rain fall straight into the "u" of "peau-rouge." Now the printed letters also seem to drip, as if the ink was 
whetted and turned back into liquid. Painted during the Easter holiday following a period of intensive assimilation, including federal bans on Indigenous dancing, the symbolic gesture of sending rainfall to France could hardly be construed as "unpremeditated" (Dunn 281). Engendering an interplay of painted figures and printed words, the artist enlarged the performance culture of Paris-indeed, the whole scope of transatlantic modernity-to accommodate the worldly address of Hopi spirituality and aesthetics.

\section{BIBLIOGRAPHY}

ADAMOWICZ, Elza. Surrealist Collage in Text and Image: Dissecting the Exquisite Corpse. Cambridge: Cambridge University Press, 2005.

Allan Houser: A Life in Art. Santa Fe: Museum of New Mexico, 1991.

ANTHES, Bill. "Making Pictures on Baskets: Modern Indian Painting in an Expanded Field." Mapping Modernisms: Art, Indigeneity, Colonialism. Eds. Elizabeth Harney and Ruth B. Phillips. Durham: Duke University Press, 2018, p. 91-109.

---. Native Moderns: American Indian Painting, 1940-1960. Durham: Duke University Press, 2006.

ARCHAMBAUD, Jean. “Cependant qu'on inaugure la maison de Washington à Vincennes:

L'interview de Mais Vert.” Paris-soir, vol. 27, May 1931.

Archives Paul Coze/Wakanda: Collection Daniel DuBois. Tessier Sarrou \& Associés auction, April 10, 2015. Paris: Drouot, 2015.

BENJAMIN, Walter. The Arcades Project. Ed. Rolf Tiedemann. Translated from the French by Howard Eiland and Kevin McLaughlin. Cambridge: Belknap Press, 2002.

---. "The Work of Art in the Age of Mechanical Reproduction." 1936. New York: Schocken Books, 2007.

BERLINER, Brett A. Ambivalent Desire: The Exotic Black Other in Jazz-Age France. Amherst: University of Massachusetts Press, 2002.

BERNSTEIN, Bruce, and W. Jackson Rushing. Modern by Tradition: American Indian Painting in the Studio Style. Albuquerque: Museum of New Mexico Press, 1995.

BERLO, Janet C. "The Szwedzicki Portfolios: Native American Fine Art and American Visual Culture, 1917-1952." Parts 1 and 2, American Indian Art Magazine, vol. 34, nos. 2-3, 2009, p. 36-45; 58-67.

BLAKE, Jody. Le Tumulte Noir: Modernist Art and Popular Entertainment in Jazz-Age Paris, 1900-1930. Philadelphia: Pennsylvania State University Press, 2003.

BRETON, André. Nadja. 1928. Translated from the French by Richard Howard. New York: Grove Press, 1994.

BRODER, Patricia. Earth Songs, Moon Dreams: Paintings by American Indian Women. New York: Macmillan, 1999. 
BRODY, J. J. Indian Painters and White Patrons. Albuquerque: University of New Mexico Press, 1971. ---. Pueblo Indian Painting: Tradition and Modernism in New Mexico, 1900-1930, Santa Fe, NM: School of American Research Press, 1997.

BURNS, Emily C. “Art, Ethnography and Politics: the Transnational Context of Bierstadt's The Last of the Buffalo in Paris." Albert Bierstadt: Witness to a Changing West. Ed. Peter H. Hassrick. Norman: University of Oklahoma Press, 2018, p. 123-150.

---. Transnational Frontiers: The American West in France. Norman: University of Oklahoma Press, 2018.

BURT, Ramsay. Alien Bodies: Representations of Modernity, Race and Nation in Early Modern Dance. Hoboken: Taylor \& Francis Ltd., 1998.

CLIFFORD, James. "On Ethnographic Surrealism." Comparative Studies in Society and History, vol. 23, no. 4,1981 , p. 539-564.

CONKLIN, Alice L. "Skulls on Display: The Science of Race in Paris's Musée de l'Homme, 1928-1950." Museums and Difference. Ed. Daniel J. Sherman. Bloomington: Indiana University Press, 2007, p. 250-288.

COWLING, Elizabeth. "The Eskimos, the American Indians and the Surrealists." Art History, vol. 1, no. 4,1978 , p. 484-500.

COZE, Paul. “L'Art sauvera-t-il les Peaux-Rouges?” ABC Magazine d'art, vol. 11, no. 127, 1935, p. 174-77.

---. “Les Indiens Peints par Eux-Mêmes." L'Illustration, vol. 94, no. 4861, 1936, p. 13-16.

---. Letter to Jacques de Baroncelli, March 21, 1931. DuBois private collection, PR38.

---. L'Oiseau-Tonnerre: Paysages et magie peaux-rouges. Paris: Éditions Je Sers, 1938.

---. Quatre feux. Paris: Éditions Revue Camping, 1935.

---. "Surprise-party peau-rouge." Unpublished typed manuscript, n.d. Paul Champetier private collection.

---. Wakanda. Paris: A. Redier, 1929.

DELEUZE, Gilles and Félix Guattari, A Thousand Plateaus. Translated from the French by Brian Massumi. Minneapolis: University of Minnesota Press, 1987.

DELORIA, Philip J. Indians in Unexpected Places. Lawrence: University Press of Kansas, 2004.

---. Playing Indian. New Haven: Yale University Press, 1999.

DELORIA, JR., Vine. Custer Died for Your Sins: An Indian Manifesto. Norman: University of Oklahoma Press, 1988.

DENZIN, Norman K. Indians on Display: Global Commodification of Native America in Performance, Art, and Museums. Walnut Creek: Left Coast, 2013.

DROIT, Michel. Le fils unique. Paris: Plon, 1988.

D'SOUZA, Aruna and Tom McDonough, eds. The Invisible Flâneuse? Gender, Public Space, and Visual Culture in Nineteenth-Century Paris. Manchester: Manchester University Press, 2006.

DuBOIS, Daniel. “Indianism in France.” European Review of Native American Studies, vol. 7, no. 1, 1993, p. 27-36. 
DUNN, Dorothy. American Indian Painting of the Southwest and Plains Areas. Albuquerque: University of New Mexico Press, 1968.

FLINT, Kate. The Transatlantic Indian, 1776-1930. Princeton: Princeton University Press, 2009.

GRAHAM, Laura R., and H. Glenn Penny, eds. Performing Indigeneity: Global Histories and Contemporary Experiences. Lincoln: University of Nebraska Press, 2014.

GRITTON, Joy L. The Institute of American Indian Art: Modernism and U.S. Indian Policy. Albuquerque: University of New Mexico Press, 2000.

HIGHWATER, Jamake. Songs from the Earth: American Indian Painting. Boston: New York Graphic Society, 1976.

HORTON, Jessica L. “A Cloudburst in Venice: Fred Kabotie and the U.S. Pavilion of 1932.” American Art, vol. 29, no. 1, 2015, p. 54-81.

---. “Ojibwa Tableaux Vivants: George Catlin, Robert Houle, Transcultural Materialism.” Art History, vol. 39, no. 1, 2016, p. 124-151.

---. "Plural Diplomacies Between Indian Termination and the Cold War: Contemporary American Indian Paintings in the 'Near East,' 1964-66." Journal of Curatorial Studies, vol. 5, no. 3, 2016, p. 340-366.

"Indiens d'Amérique du Nord et estampes. Galerie Michelle Champetier, Cannes, France, July 15, 2009-January 15, 2010. Online exhibition archive. Accessed 27 May 2017. www.mchampetier.com/sitephp/phpfr/det_cim.php? id_cim_art=8\&p=7\&PHPSESSID=e119b84c8d8c94e7de79b4253617b8df.

JONES, Caroline A. Eyesight Alone: Clement Greenberg's Modernism and the Bureaucratization of the Senses. Chicago: University of Chicago Press, 2008.

JONNES, Jill. Eiffel's Tower: And the World's Fair Where Buffalo Bill Beguiled Paris, the Artists Quarreled, and Thomas Edison Became a Count. New York: Penguin Books, 2010.

KALIFA, Dominique. “Archéologie de l'Apachisme: Les représentations des Peaux-Rouges dans la France du XIX ${ }^{\mathrm{e}}$ siècle." Revue d'histoire de l'enfance, no. 4, 2002, doi: 10.4000/rhei.51. Accessed 11 Jan. 2018.

KASSON, Joy S. Buffalo Bill's Wild West: Celebrity, Memory, and Popular History. New York: Hill and Wang, 2001.

LARGE, David C. Between Two Fires: Europe's Path in the 1930s. New York: W. W. Norton \& Company, 1991.

MAURER, Evan. "Dada and Surrealism." "Primitivism" in 20th Century Art: Affinity of the Tribal and the Modern, Vol. II. Ed. William Rubin. New York: Museum of Modern Art, 1984, p. 535-593.

MALNIG, Julie. Dancing Till Dawn: A Century of Exhibition Ballroom Dance. New York: New York University Press, 1995.

McBRIDE, Bunny. Molly Spotted Elk: A Penobscot in Paris. Norman: University of Oklahoma Press, 1995.

McGEOUGH, Michelle. Through Their Eyes: Indian Painting in Santa Fe, 1918-1945. Santa Fe: Wheelwright Museum of the American Indian, 2009.

McLERRAN, Jennifer. A New Deal for Native Art: Indian Arts and Federal Policy, 1933-1943. Tuscon: University of Arizona Press, 2009. 
MORTON, Patricia A. Hybrid Modernities: Architecture and Representation at the 1931 Colonial Exposition, Paris, Cambridge: MIT Press, 2000.

MÜLLER, Martin, “Assemblages and Actor-networks: Rethinking Socio-material Power, Politics and Space." Geography Compass, vol. 9, no. 1, 2015, p. 27-41.

OSKOMON, Charlie and Paul Coze. Green Corn Offering: Twenty-Two American Indian Poems. Paris: Wakanda, 1936.

PEARLSTONE, Zena, ed. Katsina: Commodified and Appropriated Images of Hopi Supernaturals. Los Angeles: UCLA Fowler Museum of Cultural History, 2001.

“Peaux rouges d'hier et d'aujourd'hui." Grand Gala program, May 31, 1932. Daniel DuBois private collection.

PELTIER-CAROFF, Carine. "Paul Coze, un scout ethnographe au musée d'Ethnographie du Trocadéro." Le scalp et le calumet : imaginer et représenter l'Indien en Occident du XVI siècle à nos jours. Paris: Somogy, 2017, p. 220-221.

---. "Un potlatch au Trocadéro : Paul Coze, indianist ethnographe." Les années folles de l'ethnographie: Trocadéro 28-37. Eds. André Delpuech, Christine Laurière, and Carine Peltier-Caroff. Paris: Muséum national d'Histoire naturelle, 2017, p. 481-535.

PERLMAN, Barbara H. Allan Houser. Washington, D.C.: Smithsonian Institution Press, 1991.

PENNEY, David W., and Lisa A. Roberts. “America's Pueblo Artists: Encounters on the Borderlands" Native American Art in the Twentieth Century: Makers, Meanings, Histories. Ed. W. Jackson Rushing, New York: Routledge, 1999, p. 21-38.

PHILLIPS, Ruth B. "Performing the Native Woman: Primitivism and Mimicry in Early TwentiethCentury Visual Culture." Antimodernism and Artistic Experience: Policing the Boundaries of Modernity. Ed. Lynda Jessup. Toronto: University of Toronto Press, 2001, p. 26-49.

PRATT, Mary Louise. “Arts of the Contact Zone.” Profession, no. 91, 1991, p. 33-40.

ROSALDO, Renato. “Imperialist Nostalgia." Representations, no. 26, 1989, p. 107-22.

RUSHING, W. Jackson. Allan Houser: An American Master. New York: Harry N. Abrams, 2004.

---. Generations in Modern Pueblo Painting: The Art of Tonita Peña and Joe Herrera. Norman: Fred T. Jones Museum of Art, 2018.

SALANON, René. The Heritage of French Poster Art. Paris: Bibliothèque des arts décoratifs, 1966.

SCOTT, David. Poetics of the Poster: The Rhetoric of Image-Text. Liverpool: Liverpool University Press, 2011.

SCOTT, Sascha T. “Awa Tsireh and the Art of Subtle Resistance." Art Bulletin, vol. 95, no. 4, 2013, p. 597-622.

SECAKUKU, Alph H. "Katsinam: The Katsina Dolls in Pueblo Culture and as Depicted by Georgia O’Keeffe.” Georgia O'Keeffe in New Mexico. Eds. Barbara Buhler Lynes and Carolyn Kastner. Albuquerque: Museum of New Mexico Press, 2012, p. 111-118.

SEYMOUR, Tryntje Van Ness. When the Rainbow Touches Down: The Artists and Stories behind the Apache, Navajo, Rio Grande Pueblo and Hopi Paintings in the William and Leslie Van Ness Denman Collection. Phoenix, Heard Museum, 1988.

SPOTTED ELK, Molly. "Beautiful Maine Princess Receives Great Praise in Paris.” Portland Sunday Telegram, June 14, 1931. 
---. Letter to James Allen, 26 Sept. n.y. Daniel DuBois private collection, CA51.

STANDING BEAR, Luther. 1928. Souvenirs d'un chef Sioux (My People the Sioux). Translated from the English by R. Gauillard. Paris: Payot, 1931.

STANSELL, Amanda. "Surrealist Racial Politics at the Borders of 'Reason': Whiteness, Primitivism and Négritude." Surrealism, Politics and Culture. Eds. Raymond Spiteri and Donald LaCoss. Haunts: Ashgate Publishing Limited, 2003, p. 111-126.

Tegayo, Santa Fe Indian School newsletter, December 1934. MQB Paul Coze-SF13.

TYTHACOTT, Louise. Surrealism and the Exotic. London: Routledge, 2003.

UNKALUNT, Atalie. Letter to Paul Coze, 10 June 1935. Daniel DuBois private collection, CA16.

VALÉRY, Paul. “Discours de l'histoire.” Variété IV, 1938, p. 140.

WEBER, Eugen J. The Hollow Years: France in the 1930s. New York: W.W. Norton \& Co., 1996.

WHITE DEER, Esther. Correspondence with Paul Coze, Western Union Telegram, New York December 14, 1934. Daniel DuBois private collection, CA17.

WILSON, Elizabeth. “The Invisible Flâneur.” New Left Review, no. 191, 1992, p. 90-110.

WOLFF, Janet. "The Invisible Flâneuse: Women and the Literature of Modernity." Theory, Culture \& Society, vol. 2, no. 3, 1985, p. 37-46.

WYCKOFF, Lydia L., editor. Visions and Voices: Native American Paintings from the Philbrook Museum of Art. Tulsa: Philbrook Museum, 1996.

YENNE, Bill. Indian Wars: The Campaign for the American West. Yardley: Westholme Publishing, 2008.

\section{APPENDIXES}

Image gallery: https://wp.auburn.edu/transatlantica-imagegalleryhortonperformingpaint/index.php/2019/05/12/annex-gallery-the-posters/

2022 update: the gallery is now hosted by University of Oklahoma (https:// sites.create.ou.edu/hortonperformingpaint/).

\section{NOTES}

1. I thank Emily C. Burns, Agathe Cabau, Cécile Roudeau, and two anonymous reviewers for guiding this essay to publication. Carine Peltier-Caroff was a generous contributor to my research. I am grateful to Patrick Bertrand, Michelle Champetier, Diana Bird, David Rettig, Patrick Bureau, Daniel DuBois, Veerle Thielemans, W. Jackson Rushing, Janet Catherine Berlo, Rachel Haidu, A. Joan Saab, Eleana Kim, and many others who shared materials and feedback. I thank Stewart Koyiyumptewa of the Hopi Cultural Preservation Office for reviewing several images. This research was supported by the Terra Foundation for American Art, the Center for Advanced Study in the Visual Arts, and the Center for Material Culture Studies at the University of Delaware.

Each poster also lists the Muséum national d'Histoire naturelle (MNHN), a separate institution that was formally connected to the MET in 1928 when Paul Rivet, a leading Americanist anthropologist, assumed dual positions as chair of anthropology at the MNHN and director of the 
MET (Conklin 257-258). A school newsletter notes that 28 student paintings were sent to Paris on December 5, 1934 (Tegayo 1), while Studio School instructor Dorothy Dunn notes that 100 paintings were included in the final exhibition (281).

2. This extensive material was formerly in the private collection of Daniel DuBois, a French designer and author. I was permitted to take notes (but not photographs) at DuBois's home in 2011, before the collection was dispersed at an auction in 2015 (Archives Paul Coze/Wakanda: Collection Daniel DuBois). I documented additional archives and Native American objects that belonged to Coze in the private collection of Patrick Bertrand in Cannes in 2011. A small portion of his collection is featured in the online archive for an exhibition (Indiens d'Amérique du Nord et estampes).

3. MoCNA, the museum of the federally funded Institute of American Indian Arts that replaced the Santa Fe Indian School in 1962, displayed a selection of the posters among their inaugural exhibitions in 1992. Two posters from the MoCNA collection were reproduced in the book accompanying an exhibition (McGeough 41). The Musée d'Ethnographie du Trocadero underwent renovation in the 1930s to improve the clutter of inherited collections. It closed in August of 1935 to make way for the opening of the rationalist, universalist Musée de l'Homme in 1937 (Clifford). In addition to the four damaged posters acquired by the Musée du quai Branly from the DuBois collection, two in the MoCNA collection appear to have been folded in order to hide the text. Given the discoloration that resulted from uneven exposure to light, I surmise that this was for the purposes of framing the images.

4. Notable exceptions by Daniel DuBois and Carine Peltier-Caroff are cited throughout. My essay also builds on Janet Catherine Berlo's research into six portfolios featuring pochoir prints of Native American art published by C. Szwedzicki in Nice, France, including volumes dedicated to the Kiowa painters in 1929 and Pueblo painters in 1932.

5. "Wakanda" is the name of an Omaha deity. Coze used the name for his second book in 1929, as well as for a romantic narrative film featuring Oskomon in 1934. Only still photographs from the latter are known to have survived, now in the Musée du quai Branly collection.

6. Here I note the introduction of Clement Greenberg's doctrine of "pure form" into postwar modernist discourses (Jones), although claims about the ontological distinctness of artistic mediums are widespread.

7. I have explored this conjunction in relation to tableaux vivants performed by nineteenthcentury Indigenous travelers to Paris (Horton 2016a).

8. Similar expressions of discontent fueled artistic experimentation after the Studio School reopened as the Institute of American Indian Arts (IAIA) in 1962, where Houser taught sculpture until 1974 (Perlman 141-157).

9. Based on these similarities, it is possible that Coze or another artist created a freehand copy of Howe's poster.

10. At least one student involved in the poster commission, Steven Vicente (Jicarilla Apache), later pursued a career in cattle ranching and won rodeo championships (Dunn 353; see A32).

11. In addition to Houser, Howe, and Moquino, Diné artist Narcisco Abeyta (Ha So De) and an unidentified painter, "Yazzie," signed their posters. Based on a combination of style, subject matter, and other factors, I have identified with near certainty the creators of eight additional posters: Narcisco Abeyta (A33, A44), Harrison Begay (A3), Mary Ellen (A59), Eileen Lesarlley (A12), Andrew Tsihnahjinnie (A10), Steven Vicente (A32), and Sybil Yazzie (A58).

12. The full title, L'Oiseau-Tonnerre: Paysages et magie peaux-rouges, translates as "Thunderbird: Redskin Landscapes and Magic."

13. Timothy Begay of the Navajo Nation Historical Preservation Office suggested that this image may be a hybrid of Diné and Pueblo elements, in an instance of transindigenous sharing that was common at the Studio School. 
14. The painting that is not reproduced in this essay is Allan Houser, Buffalo Hunter, 1935, watercolor on paper, 13 3/8 x 10 1/4 in., Museum of Indian Arts and Cultures, 53992/13.

15. I thank the anonymous reviewer who suggested this reading.

16. Coze immigrated to the United States in 1938, settling first in California.

17. Coze stopped in New York in 1930, where he met the collector George Gustav Heye and subsequently contributed a large collection of Assiniboine material to the Heye Foundation, the predecessor of the Smithsonian Institution National Museum of the American Indian. His trips are described in two of his books, Wakanda in 1929 and Quatre feux in 1934.

18. "Green Corn" was Coze's translation of "Oskomon."

19. Spotted Elk was preceded by Luther Mathó Nážin (Luther Standing Bear), a Lakota man who published an account of his travels in Europe with Buffalo Bill Cody's Wild West Show in 1902; a second edition published in French by Payot in 1931 featured text by Coze. Other records by Native travelers are cited and discussed throughout Burns, 2018a.

20. Archambaud later died in the German invasion of Paris and Spotted Elk fled with their daughter back to the United States (McBride 249-278).

21. Spotted Elk was suspicious of Oskomon's Indigenous credentials. She wrote in her diary in 1931, "Oskomon strikes me as a good showman, but ignorant of real Indian art, music, dances and mythology [...] Studied him, saw picture of his father-typical negro type. Must be from the Carolinas or the southern Atlantic seaboard [...] He's no more a chief than he is a Yakima [...] but I won't disturb him" (McBride 193). She stopped appearing with him on stage in 1933. Oskomon seemed to cross a line between playing and being that Spotted Elk found important to assert, even -or perhaps, especially-in the fluid entertainment culture of Paris.

22. This entailed negotiating Pueblo protocols that govern the circulation of potent ceremonial images and objects (S. Scott).

\section{ABSTRACTS}

This essay examines sixty-one extant posters that were hand-painted by students at the Studio School of the Santa Fe Indian School and sent to Paris to advertise an exhibition of their artwork, Art peau-rouge d'aujourd'hui (Redskin Art Today), at the Musée d'Ethnographie du Trocadéro in 1935. A collaboration between the students and Paul Coze, a French hobbyist and self-trained ethnographer, the commission was a dynamic component of a transatlantic assemblage that included Native objects and performers in Paris. Framed by printed French text, the figures that populated the posters engaged playfully with the city's streets, museums, and stages, demonstrating the mutual porousness of graphic and performing arts. I show that although the students could not travel in the flesh, they claimed a space for Indigenous cultural values and experiences of modernity in the French capital.

Cet essai analyse soixante et une affiches peintes à la main par les étudiants de l'école-atelier de la Santa Fe Indian School et envoyées à Paris pour annoncer l'exposition de leurs œuvres au Musée d'Ethnographie du Trocadéro en 1935, une exposition intitulée Art peau-rouge d'aujourd'hui. La collaboration entre les étudiants et Paul Coze, amateur français et ethnographe autodidacte, constituait l'élément dynamique d'un assemblage transatlantique comprenant objets autochtones et artistes amérindiens à Paris. Encadrés par un texte français imprimé, les personnages qui peuplaient les affiches étaient engagés dans un jeu ludique à travers les rues, les 
musées et les différentes scènes de la ville, démontrant la porosité entre arts graphiques et arts de la scène. Les étudiants, bien que ne pouvant pas voyager, revendiquaient ainsi - c'est l'hypothèse de cet article - un espace ouvert aux valeurs culturelles autochtones et à leur expérience de la modernité dans la capitale française.

\section{INDEX}

Keywords: Santa Fe Indian School, Studio School, Allan Houser, Dorothy Dunn, Paul Coze, Molly Spotted Elk, Surrealism, Native American, Indigenous, posters, painting, performance, assemblage, transnationalism, anticolonialism, modernisms

Mots-clés: Santa Fe Indian School, Studio School, Allan Houser, Dorothy Dunn, Paul Coze, Molly Spotted Elk, Surréalisme, Indiens d'Amérique, affiches, peinture, performance, assemblage, transnationalisme, anticolonialisme, modernisms

\section{AUTHOR}

\section{JESSICA L. HORTON}

Department of Art History, University of Delaware

jhorton@udel.edu 